Louisiana State University

LSU Digital Commons

6-14-2012

Carbon Sequestration And Sediment Accretion In San Francisco Bay Tidal Wetlands

John C. Callaway

Evyan L. Borgnis

R. Eugene Turner

Charles S. Milan

Follow this and additional works at: https://digitalcommons.Isu.edu/oceanography_coastal_pubs

Part of the Oceanography Commons 


\title{
Carbon Sequestration and Sediment Accretion in San Francisco Bay Tidal Wetlands
}

\author{
John C. Callaway • Evyan L. Borgnis • \\ R. Eugene Turner $\cdot$ Charles S. Milan
}

Received: 30 August 2011 /Revised: 4 February 2012 / Accepted: 17 April 2012 /Published online: 14 June 2012

(C) Coastal and Estuarine Research Federation 2012

\begin{abstract}
Tidal wetlands play an important role with respect to climate change because of both their sensitivity to sea-level rise and their ability to sequester carbon dioxide from the atmosphere. Policy-based interest in carbon sequestration has increased recently, and wetland restoration projects have potential for carbon credits through soil carbon sequestration. We measured sediment accretion, mineral and organic matter accumulation, and carbon sequestration rates using ${ }^{137} \mathrm{Cs}$ and ${ }^{210} \mathrm{~Pb}$ downcore distributions at six natural tidal wetlands in the San Francisco Bay Estuary. The accretion rates were, in general, $0.2-0.5 \mathrm{~cm}_{\text {year }}{ }^{-1}$, indicating that local wetlands are keeping pace with recent rates of sea-level rise. Mineral accumulation rates were higher in salt marshes and at low-marsh stations within individual sites. The average carbon sequestration rate based on ${ }^{210} \mathrm{~Pb}$ dating was $79 \mathrm{~g} \mathrm{C} \mathrm{m}^{-2}$ year $^{-1}$, with slightly higher rates based on ${ }^{137} \mathrm{Cs}$ dating. There was little difference in the sequestration rates among sites or across stations within sites, indicating that a single carbon sequestration rate could be used for crediting tidal wetland restoration projects within the Estuary.
\end{abstract}

Keywords Brackish marsh - Carbon offsets · Climate change $\cdot$ Mineral matter accumulation $\cdot$ Organic matter

\footnotetext{
J. C. Callaway $(\triangle) \cdot$ E. L. Borgnis

Department of Environmental Science,

University of San Francisco,

2130 Fulton St,

San Francisco, CA 94117, USA

e-mail: callaway@usfca.edu

R. E. Turner $\cdot$ C. S. Milan

Department of Oceanography and Coastal Sciences,

Louisiana State University,

Baton Rouge, LA 70803, USA
}

accumulation · Salt marsh · San Francisco Bay Estuary · Sealevel rise $\cdot$ Sedimentation

\section{Introduction}

Climate change directly affects tidal wetlands, primarily through changes in the rate of sea-level rise (SLR; Michener et al. 1997; Morris et al. 2002), and most, but not all, tidal wetlands have accumulated enough sediment to keep pace with recent rates of SLR of 1-3 mm year ${ }^{-1}$ (e.g., see summaries in Stevenson et al. 1986; Allen 2000; Callaway 2001; Friedrichs and Perry 2001). However, if the sea level rises $1 \mathrm{~m}$ or more by 2100 , as has been predicted by some (Rahmstorf 2007; Vermeer and Rahmstorf 2009), then the ability of tidal wetlands to survive is uncertain (Kirwan et al. 2010). Furthermore, there is potential for substantial variation in sediment dynamics across the range of tidal wetland types and within individual wetlands as the sediment load changes with land use or freshwater discharge and as wetland plant communities shape these dynamics. The end of the Mississippi River delta, for example, has grown and shrunk over the last 200 years as sediment supply changed with land clearing and as dams were built (Tweel and Turner 2012).

Tidal wetlands play a role in buffering climate change by sequestering carbon (Chmura et al. 2003; Bridgham et al. 2006), and they are particularly effective at doing this because of their high primary productivity, ongoing sediment deposition, and relatively low decomposition rates (Connor et al. 2001; Hussein et al. 2004). The few studies evaluating how carbon sequestration rates vary across or within particular wetland complexes describe a wide range of rates (Craft 2007; McLeod et al. 2011), with many factors potentially affecting net carbon sequestration, including local plant 
species composition and productivity, decomposition rates, allochthonous sediment imports, salinity, tidal range, and human activities. In particular, a number of studies have found higher rates of carbon sequestration in tidal wetlands with lower salinity (e.g., Craft 2007).

Policy-based interest in carbon sequestration has increased significantly as federal and state governments, as well as international agencies, consider the possibility of incorporating carbon credits for tidal wetland restoration into their plans to develop both voluntary and regulatory carbon markets intended to reduce $\mathrm{CO}_{2}$ emissions (Freedman et al. 2009; Hansen 2009; Laffoley and Grimsditch 2009; Crooks et al. 2010). Carbon credits would be applied to tidal wetland restoration efforts, as well as to other wetland conservation activities, in order to sequester carbon that would otherwise enter the atmosphere (Emmett-Mattox et al. 2011). These credits likely would be based on carbon removed over approximately 100 years, but not for carbon that could decompose and return $\mathrm{CO}_{2}$ to the atmosphere over shorter time periods (Crooks et al. 2010). This combined focus on restored wetlands and long-term carbon storage has created a conundrum because there are few, if any, restoration sites of sufficient age to estimate long-term carbon storage. Given this problem, measuring the amount of carbon stored in natural wetlands has been identified as a potential surrogate to establish baseline values for predicting carbon sequestration rates in restored sites. This approach assumes that restored and natural sites will behave in a similar manner over a timescale of centuries.

Tidal freshwater wetlands may have high rates of carbon burial (Craft 2007; Neubauer 2008), but they also can emit substantial amounts of methane, which has 25 times the greenhouse potential as carbon dioxide. This methane release to the atmosphere may be high enough to negate the benefits of carbon stored belowground (Bridgham et al. 2006; Kayranli et al. 2010; Poffenbarger et al. 2011). Saline wetlands produce little methane because the relatively high inputs of sulfate from marine waters promote sulfate reduction and minimize methane production (Bartlett and Harriss 1993; Magenheimer et al. 1996). Poffenbarger et al. (2011) reviewed a wide range of data on methane emissions and found little methane production if the soil pore water salinity was above $18 \mathrm{psu}$ and highly variable emissions below this level. Because of concerns over methane production in freshwater wetlands, much of the interest in developing carbon credits for tidal wetland restoration has focused on saline wetlands. However, some managed freshwater sites may accumulate enough carbon to result in net carbon storage (Miller and Fujii 2010). It is necessary, therefore, to evaluate the variations in carbon sequestration rates across salinity gradients, within wetlands types (i.e., within salt marshes), and within locations to determine what credits might be awarded for future wetland restoration activities.
There is substantial interest in tidal wetland restoration in California, where large-scale restoration projects are underway or planned in the San Francisco Bay Estuary (e.g., Montezuma Wetlands in Suisun Bay, Hamilton Wetlands, the Napa-Sonoma Salt Pond Project, and the South Bay Salt Pond Project) and elsewhere (e.g., Bolsa Chica Wetlands in Huntington Beach and San Deiguito Lagoon in San Diego). The State of California passed Assembly Bill 32: The Global Warming Solutions Act in 2006, which set up the framework for a carbon trading program within the state as a way to accommodate emission reductions for large-scale emitters who will be forced to meet statewide emission reductions over the coming decades. The state is currently working to develop protocols for activities, such as tidal wetland restoration, that will receive carbon credits under the trading program (see http://www.arb.ca.gov/cc/cc.htm). Numerous studies have evaluated accretion rates and carbon dynamics on the Atlantic and Gulf Coasts (see compilations in Stevenson et al. 1986; Turner et al. 2000; Callaway 2001); however, these wetlands are dominated by Spartina alterniflora and Spartina patens and are quite different from the tidal wetlands in the San Francisco Bay Estuary (hereafter, Estuary) which are mostly dominated by perennial pickleweed, Sarcocornia pacifica, formerly Salicornia virginica (Emmett et al. 2000; Callaway et al. 2012). Because of these issues and others, it is risky to conclude that what has been learned about sediment and carbon dynamics in S. alterniflora and S. patens wetlands is directly applicable to Mediterranean-type tidal wetlands like those found in the Estuary and along much of the Pacific Coast. While a number of studies have looked at long-term sediment and carbon dynamics in the Estuary using ${ }^{14} \mathrm{C}$-based dating methods (e.g., Watson 2004; Drexler et al. 2009), very few data exist for the Estuary or elsewhere on the Pacific Coast on the scale of 50-100 years, which is the timescale of interest for policy needs. Only one prior study used ${ }^{137} \mathrm{Cs}$ profiles to measure sediment accretion rates in San Francisco Bay salt marshes, with one core per site across three sites in South San Francisco Bay (Patrick and DeLaune 1990). No prior measurements of wetland sedimentation have been completed in the Estuary using ${ }^{210} \mathrm{~Pb}$-based dating.

The objectives of our research were to evaluate the ability of salt and brackish tidal wetlands in the Estuary to keep pace with sea-level rise through sediment accretion and to estimate the potential for wetland carbon sequestration. We measured the rates of vertical accretion, as well as mineral matter, organic matter, and carbon accumulation, within six wetlands using two different dating methods. We also compared soil characteristics from natural and restored salt marshes in the Estuary to evaluate the use of natural wetlands as surrogates in studies of the carbon dynamics within restored wetlands. We hypothesized that: 
1. Sediment accretion, carbon, and mineral matter accumulation rates are higher in tidal brackish wetlands compared to in salt marshes.

2. Sediment accretion, carbon, and mineral matter accumulation rates within individual wetlands are highest closer to the bay margin or large tidal creeks and lowest at more inland locations.

\section{Methods and Materials}

\section{Site Locations}

We collected sediment cores from six natural and two restored tidal wetlands in the Estuary (Fig. 1). Four of the natural sites were saline wetlands, including: Whale's Tail (WT), China Camp (CC), Petaluma River Marsh (PRM), and Coon Island (CI). We originally thought that the WT site was a historical wetland like the rest of our natural sites, only to discover later that it was close to 100 years old. Two sites were tidal brackish wetlands: Rush Ranch (RR) and Browns Island (BRI). Additional sediment cores were collected from two restored salt marshes: Cogswell Marsh (CM) in South SF Bay and Muzzi Marsh (MM) in the North Bay. Cogswell Marsh was restored in 1980 and Muzzi Marsh in 1976 (Williams and Faber 2001). Cores were not collected from restored brackish wetlands because there are few existing restored brackish sites in the Estuary. The cores from the two restored wetlands could not be dated using radioisotopic methods because of their relatively young age. The soil characteristics of these restored sites, however, were compared to data from the natural wetlands.

The saline sites are generally dominated by Spartina foliosa in the area adjacent to the bay margin and in a narrow margin along tidal creeks and by S. pacifica throughout the broad marsh plain. The brackish wetland sites are typically dominated by Schoenoplectus acutus or Schoenoplectus californicus adjacent to creeks and the bay margin, with the marsh plain areas dominated by S. pacifica, Schoenoplectus americanus, Distichlis spicata, and other species whose relative proportions depend on variations in salinity (Table 1). The Coon Island wetland has a lower salinity range than the other salt marshes and includes a mix of salt and brackish wetland vegetation. Based on vegetation, the Coon Island wetland could be considered a brackish wetland; however, based on soil characteristics and sediment relationships (see "Results"), it is more similar to the other salt marshes than to the brackish wetlands. Two of the salt marsh sites (WT and CC) are located on the edge of the Estuary where there is little local freshwater input. The two other salt marsh sites are on the Petaluma River (PRM) and
Napa River (CI) and are approximately 7.5 and $10 \mathrm{~km}$ upriver of the major bay shoreline, respectively. One of the brackish sites (RR) is in northern Suisun Bay and is somewhat removed from the direct influence of the river, while the other brackish site (BRI) is located at the confluence of the Sacramento and San Joaquin Rivers on the western edge of the Sacramento-San Joaquin Delta and the eastern edge of Suisun Bay (Fig. 1).

Soil Sampling, Soil Properties, Carbon Analysis, and Dating Techniques

Each site had six stations distributed in the low, middle, and high areas along two parallel transects (Fig. 1). We used ArcGIS to randomly identify multiple potential starting points for transects originating in the upper portion of each wetland (adjacent to upland areas for most sites or the central portion of island sites); two of these potential starting points were randomly chosen as the beginning of each transect. The lower end of the transect was oriented in the direction of the bay or the nearest large tidal creek $(>10 \mathrm{~m}$ wide); the transect midpoint was halfway to the low-marsh station, which was approximately $20 \mathrm{~m}$ from the bay or creek shoreline. We collected 11 sediment cores at the Coon Island wetland along four transects to examine the spatial variation across a single site in more detail than at the other sites. We collected a total of 41 cores for dating and analysis of sediment characteristics (five sites with six cores per site and one site with 11 cores). An additional 12 cores were collected from the restoration sites (two restored sites with six cores per site) that were analyzed for sediment characteristics only.

We collected these cores from December 2008 to February 2011 using a $15-\mathrm{cm}$ diameter sharp-edged, aluminum soil coring tube (Hargis and Twilley 1994). The sample depth ranged from 48 to $54 \mathrm{~cm}$. Compaction during core collection was estimated by measuring the difference in elevation inside and outside of the coring tube to the nearest millimeter. Cores were not used if compaction was $>3 \mathrm{~cm}$, and compaction for all cores averaged $0.3 \mathrm{~cm}$. Soil cores were sectioned into $2-\mathrm{cm}$ intervals in the field and put in airtight Ziploc bags. The samples were weighed in the laboratory, dried at $85^{\circ} \mathrm{C}$ for $\sim 72 \mathrm{~h}$, and reweighed to determine their bulk density (BD). Half of the dried sample was ground with a mortar and pestle for further analysis. The elevation and location of each station were surveyed using a Leica 1200 Series Real-Time Kinematic GPS system (horizontal accuracy, $\sim 1 \mathrm{~cm}$; vertical accuracy, $\sim 3 \mathrm{~cm}$ ).

We measured the soil organic and mineral matter content of each 2-cm section using the loss-on-ignition (LOI) method (Ball 1964; Craft et al. 1991). Dried and ground subsamples were weighed, burned at $450^{\circ} \mathrm{C}$ for $8 \mathrm{~h}$, and reweighed. Soil organic matter $(\mathrm{OM})$ content can be used 
Fig. 1 Locations of sampling sites in San Francisco Bay estuary, including both natural and restored wetlands. The salt marsh sites were Whale's Tail, Cogswell Marsh (restored),

Muzzi Marsh (restored), China Camp, Petaluma River Marsh; Coon Island includes a mix of brackish and salt marsh vegetation, but is classified as a salt marsh based on the sampling locations and soil conditions measured in this project. The brackish wetland sites were Rush Ranch and Browns Island

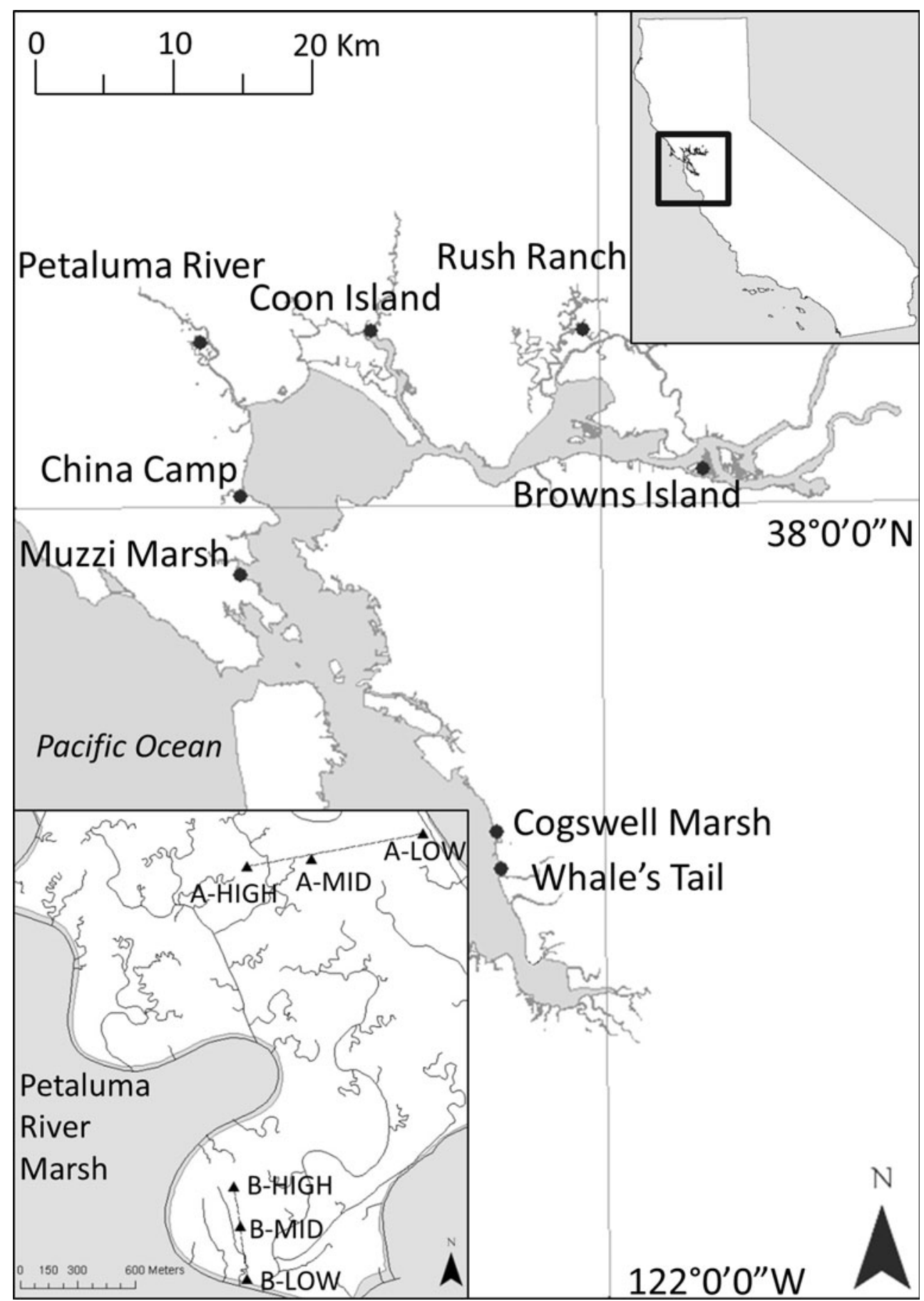

as an indirect measure of carbon content because the concentration of carbon within the OM is relatively constant (Craft et al. 1991). In order to establish a correlation between LOI measurements and carbon content, carbon content was measured directly for a subset of 2-cm sections (97 samples) using a Flash 2000 Organic Elemental Analyzer manufactured by $\mathrm{CE}$ Elantech. A standard soil reference material was analyzed every six samples throughout all carbon analyses. The relationship between OM content and carbon content from our samples was compared with that from tidal wetland sediments made by Craft et al. (1991). We measured the soil texture of composite 10-cm intervals for all cores using the hydrometer method (Gee and Bauder 1986).

The sediments were dated by determining the downcore distribution of ${ }^{210} \mathrm{~Pb}$ and ${ }^{137} \mathrm{Cs}$ activity. The radioisotope ${ }^{137} \mathrm{Cs}$, a residual of nuclear bomb fallout, first appeared in measurable amounts in the early 1950 s, peaked in the spring of 1963 with additional large amounts in early 1964, and declined to undetectable amounts after 1986, although the 


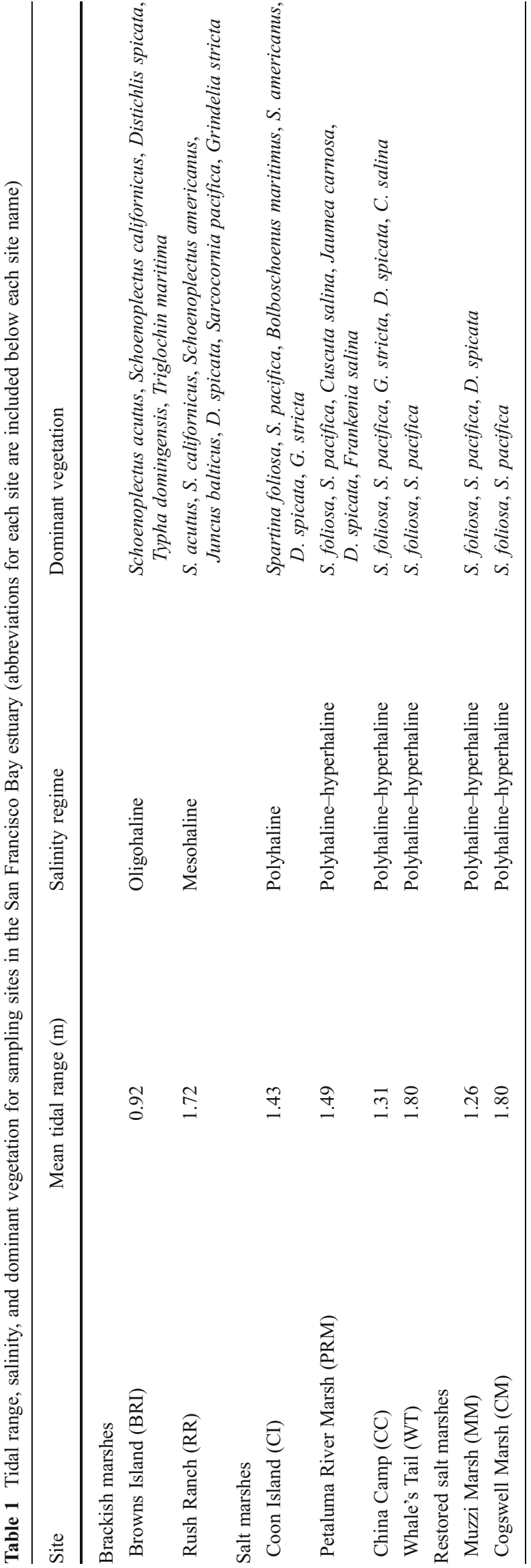

Chernobyl accident in 1986 deposited ${ }^{137} \mathrm{Cs}$ in some locations (Callaway et al. 1996a). The sediments were dated with ${ }^{137} \mathrm{Cs}$ using the peak accretion rate at the $1963 / 1964$ layer. The radioisotope ${ }^{210} \mathrm{P}$ is naturally occurring and is continually deposited by rainfall. The disequilibrium between ${ }^{226} \mathrm{Ra}$ and its long-lived decay product ${ }^{210} \mathrm{~Pb}$ (halflife $=22.3$ years) is widely used to date aquatic and wetland sediments, but with different modeling approaches depending on sediment characteristics, radioisotopic analyses, and assumptions. ${ }^{210} \mathrm{~Pb}$ and ${ }^{137} \mathrm{Cs}$ activity was determined using an integrated gamma spectroscopy system consisting of a Princeton Gamma-Tech 60-mm diameter intrinsic germanium "N"-type coaxial detector (40\% efficiency) interfaced to an EG\&G Ortec $92 \mathrm{X}$ Spectrum Master ${ }^{\circledR}$ multichannel spectrum analyzer. We used Ortec's GammaVision ${ }^{\circledR}$ software to analyze the data. The system was calibrated using a multinuclide $(60-1836 \mathrm{keV})$ standard solution (Isotope Products no. 7600) that was mixed with an estuarine soil and then packed in a $26-\mathrm{cm}^{3}$ plastic Petri dish. ${ }^{210} \mathrm{~Pb}$ activity was determined using a Canberra LowEnergy Germanium Detector (model GL3825), which was interfaced to a Canberra Digital Spectrum Analyzer (model DSA-100), and Canberra's Genie 2000 software. The calibration of the systems was checked quarterly for ${ }^{210} \mathrm{~Pb}$ and ${ }^{137} \mathrm{Cs}$ activity with standard sediment from the International Atomic Energy Agency (IAEA-300). Samples for ${ }^{210} \mathrm{~Pb}$ were counted for about $48 \mathrm{~h}$, depending on the sample sediment qualities. The background, with an empty Petri dish, was counted every 6 days for $48 \mathrm{~h}$. The excess (unsupported) ${ }^{210} \mathrm{~Pb}$ is calculated by subtracting the supported ${ }^{210} \mathrm{~Pb}$ activity from the total ${ }^{210} \mathrm{~Pb}$ activity. The supported ${ }^{210} \mathrm{~Pb}$ was estimated from the activity of ${ }^{214} \mathrm{~Pb}$ (295 and $352 \mathrm{keV}$ ).

The accretion rates using the downcore distribution of ${ }^{210} \mathrm{~Pb}$ were calculated using the constant initial concentration model (Robbins et al. 1978). This model assumes that there is negligible migration of ${ }^{210} \mathrm{~Pb}$ and associated radionuclides in sediments, a constant input of ${ }^{210} \mathrm{~Pb}$ from the atmosphere, and a constant proportion of ${ }^{210} \mathrm{~Pb}$ trapped in sediments by weight. This model is applied under the assumption that the excess ${ }^{210} \mathrm{~Pb}$ in sediments deposited at the surface will be the same regardless of the sedimentation rate. This model uses the cumulative sedimentation rate downcore, a decay constant of ${ }^{210} \mathrm{~Pb}$, and the change of excess ${ }^{210} \mathrm{~Pb}$ activities with depth to estimate sediment accretion rates. A linear regression of the natural $\log (\ln )$ of the excess ${ }^{210} \mathrm{~Pb}$ activity vs. depth was used to estimate sedimentation rate. The activity of ${ }^{210} \mathrm{~Pb}$ in the first few centimeters of the surface can aid in determining how much mixing has occurred. Counting errors were calculated using the counting uncertainties of ${ }^{210} \mathrm{~Pb}$ and ${ }^{214} \mathrm{~Pb}$ and the formula from Binford (1990). The counting uncertainty ranged from $<10 \%$ for surface samples $(<10 \mathrm{~cm})$ to $15 \%$ 
Table 2 Average sediment organic matter content and bulk density ( \pm standard error) in the top $20 \mathrm{~cm}$ of cores from low-, mid-, and highmarsh stations at all sampling sites $(n=2$ for all stations, except $n=1$ for
Browns Island Low, Petaluma River low, Whale's Tail Mid and High, and $n=3$ for Coon Island Mid and High)

\begin{tabular}{|c|c|c|c|c|c|c|}
\hline \multirow[t]{2}{*}{ Site } & \multicolumn{3}{|c|}{ Organic matter $(\%)$} & \multicolumn{3}{|c|}{ Bulk density $\left(\mathrm{g} \mathrm{cm}^{3}\right)$} \\
\hline & Low & Mid & High & Low & Mid & High \\
\hline Browns Island & $29.3(n=1)$ & $48.6(1.40)$ & $59.5(7.42)$ & $0.29(n=1)$ & $0.18(0.001)$ & $0.16(0.019)$ \\
\hline Rush Ranch & $18.0(0.77)$ & $43.9(4.06)$ & $32.0(3.28)$ & $0.41(0.026)$ & $0.25(0.004)$ & $0.27(0.051)$ \\
\hline Brackish marsh means & 23.7 & 46.2 & 45.7 & 0.35 & 0.22 & 0.21 \\
\hline Coon Island & $13.5(5.27)$ & $19.2(4.60)$ & $18.3(1.48)$ & $0.63(0.197)$ & $0.43(0.147)$ & $0.36(0.037)$ \\
\hline Petaluma River & $7.6(n=1)$ & $16.1(4.13)$ & $25.1(1.22)$ & $0.82(n=1)$ & $0.39(0.093)$ & $0.23(0.001)$ \\
\hline China Camp & $11.7(1.92)$ & $12.7(3.81)$ & $15.9(3.33)$ & $0.52(0.108)$ & $0.46(0.066)$ & $0.47(0.082)$ \\
\hline Whale's Tail & $8.4(0.02)$ & $13.2(n=1)$ & $12.8(n=1)$ & $0.62(0.023)$ & $0.43(n=1)$ & $0.40(n=1)$ \\
\hline Salt marsh means & 10.3 & 15.3 & 18.0 & 0.65 & 0.43 & 0.37 \\
\hline Muzzi Marsh & $11.1(1.29)$ & $11.5(1.20)$ & $10.8(0.74)$ & $0.44(0.025)$ & $0.44(0.058)$ & $0.68(0.163)$ \\
\hline Cogswell Marsh & $9.3(1.80)$ & $9.0(0.26)$ & $9.2(0.34)$ & $0.62(0.001)$ & $0.55(0.054)$ & $0.53(0.026)$ \\
\hline Restored marsh means & 10.2 & 10.3 & 10.0 & 0.53 & 0.50 & 0.60 \\
\hline
\end{tabular}

for deeper samples. The sum of the excess ${ }^{210} \mathrm{~Pb}$ was estimated for each core using the interpolated values for core segments not counted and the measured dry weights.

Some cores could not be dated successfully (discussed in Milan et al. 1995) because the local area may experience disturbance, bioturbation, erosion, or rapid sediment accumulation, all of which can compromise dating quality. A set of criteria was developed to determine whether the calculated accretion rate was usable. The criteria used were: (1) agreement between the ${ }^{137} \mathrm{Cs}$ and ${ }^{210} \mathrm{~Pb}$ rates, (2) whether there was a significant amount of ${ }^{137} \mathrm{Cs}$ at the surface, and (3) the inventory of ${ }^{137} \mathrm{Cs}$ in the core. The use of ${ }^{137} \mathrm{Cs}$ as a sediment dating tool is based on the assumption that there has been a constant deposition of material to the surface and that sediment has not been removed or added. Because ${ }^{137} \mathrm{Cs}$ has not been deposited from the atmosphere since the late 1980 s, the presence of ${ }^{137} \mathrm{Cs}$ at the surface brings into question the validity of the calculated accretion rate. The expected inventory of ${ }^{137} \mathrm{Cs}$ in a core can be calculated based upon the precipitation data and atmospheric fallout records of ${ }^{137} \mathrm{Cs}$ and ${ }^{90} \mathrm{Sr}$ (Milan et al. 1995). Low or high inventories of ${ }^{137} \mathrm{Cs}$ in a core call into question whether the accretion of sediment occurred in an undisturbed manner, and thus the validity of the calculated accretion rate. Based upon these criteria, the cores were ranked as "excellent" if: the accretion rates based on the downcore distribution of ${ }^{137} \mathrm{Cs}$ and ${ }^{210} \mathrm{~Pb}$ agreed, there was no ${ }^{137} \mathrm{Cs}$ at the surface, and if the measured ${ }^{137} \mathrm{Cs}$ inventory was close to the estimated inventory. The cores were ranked "good" if the accretion rates from the ${ }^{137} \mathrm{Cs}$ and ${ }^{210} \mathrm{~Pb}$ dating methods agreed and if there was ${ }^{137} \mathrm{Cs}$ at the surface and/or a relatively high ${ }^{137} \mathrm{Cs}$ inventory. The cores were classified as "marginal" if the accretion rates from the two dating methods did not agree or if there was ${ }^{137} \mathrm{Cs}$ at surface and/ or a relatively high ${ }^{137} \mathrm{Cs}$ inventory.

We calculated the mineral, organic, and carbon accumulation rates for each core using the accretion rates determined with ${ }^{137} \mathrm{Cs}$ and ${ }^{210} \mathrm{~Pb}$, and the mineral, organic, and carbon densities (the product of bulk density and mineral, organic, or carbon content) for each $2-\mathrm{cm}$ section. The mineral, organic, and carbon densities were summed over a depth appropriate to the accretion rate and time period for a particular core and dating method to provide mass-based accumulation rates for each. The ${ }^{137} \mathrm{Cs}$-based accretion rates are for 44-46 years (from 1964 to the core collection date), and the ${ }^{210} \mathrm{~Pb}$-based accretion rates are for 100 years. Because the $\mathrm{OM}$ accumulation and carbon accumulation rates were strongly correlated and very similar, we primarily present results for carbon accumulation rates.

There was at least one successfully dated core at each of the three marsh stations (low, mid, and high) from each site, although some sites had an unequal numbers of dated cores across stations (ranging from one to three cores/station). In order to avoid excessive influence of stations with more cores, we determined averages for sites by first averaging all cores within each of the three marsh stations and then averaging these three values for each site. We conducted the statistical analyses only using data from those cores that were successfully dated (excellent, good, and marginal). We averaged the soil BD and OM contents over $0-20 \mathrm{~cm}$ (a typical rooting depth) and over the entire 0 - to $50-\mathrm{cm}$ core for the statistical analyses.

We tested for differences in soil OM content, BD, accretion rates, and mass-based accumulation rates across sites and stations using a two-way ANOVA (SYSTAT 2007), and we used Tukey's honestly significant difference test to make 

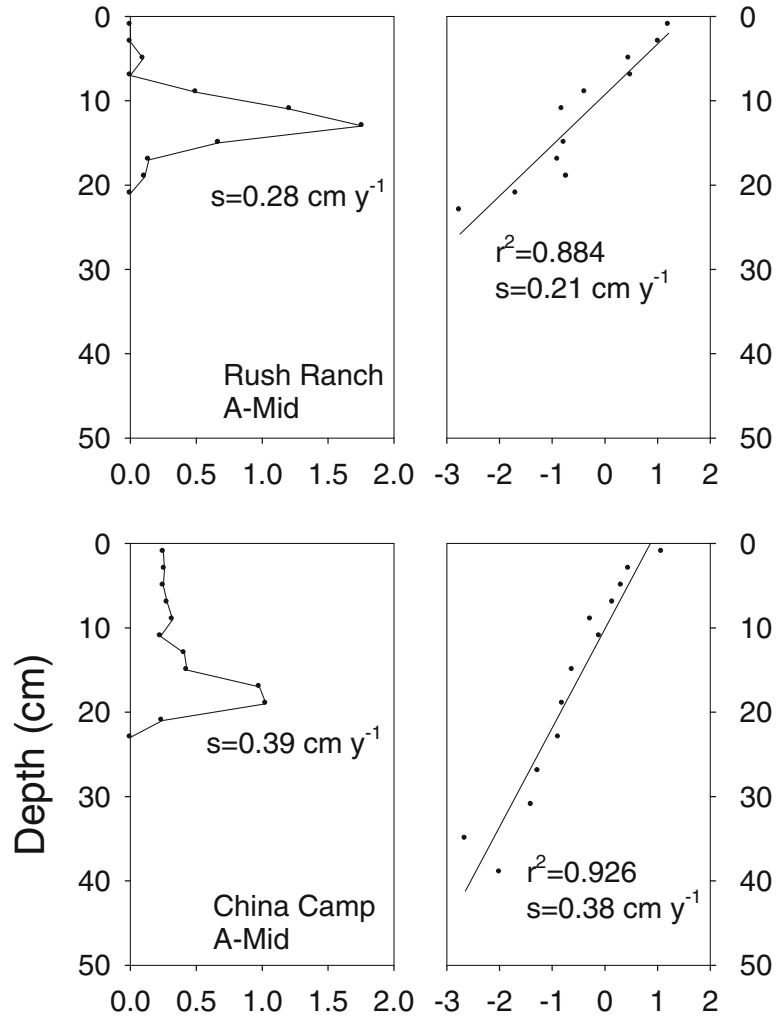

0
10 20

30 40 50

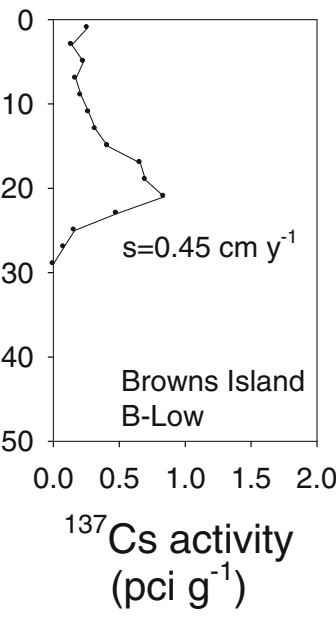

Fig. 2 Sample ${ }^{137} \mathrm{Cs}$ and ${ }^{210} \mathrm{~Pb}$ downcore distributions from tidal wetlands in San Francisco Bay estuary. The top panel shows data from a core classified as excellent, the middle panel from one classified as good, and the bottom panel from one classified as marginal

post-ANOVA comparisons. We tested for the normality and homogeneity of variance using the Kolmogorov-Smirnov test and Levene's test, respectively, and we $\log _{10}$-transformed the accretion and accumulation rates in order to better meet these assumptions. We also evaluated alternative statistical approaches to test for differences between salt and brackish wetlands or between natural and restored salt marshes (e.g., linear mixed models). However, differences were primarily due to individual sites rather than to wetland type (e.g., salt vs. brackish marshes), so these results are not included.

We conducted a linear regression analysis to evaluate the relationships between the accretion rates and mass-based accumulations rates of both mineral and organic matter (SYSTAT 2007). We used the OM accumulation rates rather than the carbon accumulation rates for these analyses to facilitate comparisons with previous analyses (Nyman et al. 1993; Callaway et al. 1997; Turner et al. 2000; Neubauer 2008). Regressions were completed for the entire dataset as a whole and also separately for the salt marsh sites and brackish marsh sites.

\section{Results}

\section{Soil Characteristics}

The sediment BD in the upper $20 \mathrm{~cm}$ was higher in lowmarsh stations than in mid- or high-marsh stations and was generally highest in salt marshes (Table 2; Appendix 1), although the BD values were only significantly different between BRI and two of the salt marsh sites (see Appendix 2 for the $\mathrm{BD}$ values of the entire $0-$ to $50-\mathrm{cm}$ core). The two restored salt marshes had $\mathrm{BD}$ values similar to the natural salt marshes in the top $20 \mathrm{~cm}$, but the BD values from the two restored salt marshes were $30-40 \%$ higher than at the natural salt marshes for samples from $0-50 \mathrm{~cm}(p=0.017$; Appendix 2). The OM content in the upper $20 \mathrm{~cm}$ was lowest at the low-marsh stations (Table 2), with most sites showing a gradual increase in OM content across the low, mid, and high stations (Table 2; Appendix 1), and the OM content was higher in both brackish wetlands than in all four salt marsh sites (Table 2; Appendix 1). The differences among salt and brackish sites were similar for OM content from $0-50 \mathrm{~cm}$, although not every salt marsh site was significantly different from the values at RR (Appendices 1 and 3). The OM content in two restored salt marshes were similar to that in the natural marshes $(\mathrm{CM}=9 \%, \mathrm{MM}=11 \%$, and four natural marshes averaged $14 \% \mathrm{OM}$ in the upper $20 \mathrm{~cm}$ ). Most of the cores exhibited the expected trends of increasing BD and decreasing OM with depth, although these patterns were less consistent for the brackish sites (Appendices 4 and 5).

The $\mathrm{BD}$ and $\mathrm{OM}$ values were strongly and inversely related (Appendix $6 ; \log _{10} \mathrm{BD}=-0.6922 \times \log _{10} \mathrm{OM}+$ $\left.0.4133, r^{2}=0.80\right)$. The $\mathrm{OM}$ and carbon content values were also highly correlated, and we used a quadratic regression similar to that developed by Craft et al. (1991) to convert the OM content to carbon content (both expressed as percent of dry weight) and to calculate carbon sequestration: Organic $\mathrm{C}=(0.001217) \times \mathrm{OM}^{2}+(0.3839) \times \mathrm{OM}\left(r^{2}=0.99 ;\right.$ Appendix 7$)$. All soils had a fine texture, and there was little sand in most 
cores $(<18 \%$ in all cores, except for CI which was $24 \%$ sand) and high levels of clay particles.

Accretion Rates and Mass-Based Accumulation Rates, Including Carbon Sequestration

We successfully dated 34 of the 41 cores collected using the downcore distributions of ${ }^{137} \mathrm{Cs}$ and 28 using the downcore distributions of ${ }^{210} \mathrm{~Pb}$ (see Fig. 2 for sample profiles). We classified four of the dated cores as "excellent," 14 as "good," and 16 as "marginal."

The accretion rates measured using the downcore distributions of ${ }^{137} \mathrm{Cs}$ were typically slightly higher than those measured using the downcore distributions of ${ }^{210} \mathrm{~Pb}$ for almost all sites and stations (see Appendix 8 for a complete listing of accretion rates and accumulation rates for individual cores). The accretion rates for most cores were between 0.2 and $0.5 \mathrm{~cm}$ year ${ }^{-1}$ ( 26 of 34 cores for ${ }^{137} \mathrm{Cs}$ and 21 of 28 cores for ${ }^{210} \mathrm{~Pb}$, with five of the outliers between 0.1 and $0.2 \mathrm{~cm} \mathrm{year}^{-1}$ ). There were few significant differences in accretion rates across sites. The accretion rate at WT based on ${ }^{137} \mathrm{Cs}$ distributions was the only individual site that was significantly greater than at the others (see Appendix 9 for details), and there were no significant differences among individual sites for the accretion rates based on the ${ }^{210} \mathrm{~Pb}$-determined distribution (Table 3; Appendix 9). Although there were few differences in accretion rates among sites, within a site the accretion rates based on ${ }^{137} \mathrm{Cs}$ distributions at the low-marsh stations were greater than at the mid- or high-marsh stations (Table 3; Appendix 9). There were never significant differences in the accretion rates or mass-based accumulation rates between the mid- and high-marsh stations regardless of the dating method.

The highest rates of mineral accumulation were found at the salt marsh sites, with significant differences across sites regardless of whether the rates were based on the ${ }^{137} \mathrm{Cs}$ or ${ }^{210} \mathrm{~Pb}$ distributions (Table 3; Appendix 9). The mineral accumulation rates also were significantly different across stations, with much higher rates at the low-marsh stations (45-450\% greater depending on sites and the dating method) than at mid- or high-marsh stations for both dating methods (Table 3; Appendix 9). These percent differences were much greater than any similar comparisons for vertical accretion rates or carbon accumulation rates.

As with accretion rates, the carbon sequestration rates based on ${ }^{210} \mathrm{~Pb}$ dating were slightly lower than those based on ${ }^{137} \mathrm{Cs}$ dating. The average rates for each site that was based on ${ }^{210} \mathrm{~Pb}$ dating ranged from 46 to $81 \mathrm{~g} \mathrm{C} \mathrm{m}^{-2}$ year $^{-1}$ at the three salt marshes and from 89 to $117 \mathrm{~g} \mathrm{C} \mathrm{m}^{-2}$ year $^{-1}$ at the two brackish wetlands. The only significant difference in carbon sequestration among individual sites based on ${ }^{137} \mathrm{Cs}$ dating was between BRI and PRM, and there were no differences in the carbon sequestration rates among sites based on the ${ }^{210} \mathrm{~Pb}$ rates (Appendix 9). Within sites, the carbon sequestration rates based on ${ }^{137} \mathrm{Cs}$ dating were higher at the low-marsh stations compared to the mid- and high-marsh stations (Appendix 9), although the magnitude of differences was much smaller than for mineral accumulation rates. In addition, there were no differences across stations for carbon sequestration rates based on ${ }^{210} \mathrm{~Pb}$ dating (Appendix 9).

Based on the results from all of the dated 34 cores, there were higher $r^{2}$ values for a simple linear regression of the relationship between the OM accumulation and vertical accretion rates than between the mineral matter accumulation and vertical accretion rates for both ${ }^{137} \mathrm{Cs}$ and ${ }^{210} \mathrm{~Pb}$ distributions (Fig. 3; Appendix 10). When the dataset was separated into salt and brackish wetland locations, the $r^{2}$ values describing the relationship between the OM accumulation and accretion rates were higher, in all cases, than the values describing the relationship between mineral matter accumulation and accretion rates (Appendix 10). The relationships were also consistently stronger for the cores from salt marsh sites compared to those from brackish wetland locations (Appendix 10), with particularly high $r^{2}$ values between OM accumulation and the accretion rates in the salt marsh $\left(r^{2}=0.87\right.$ for ${ }^{137} \mathrm{Cs}$ dating; $r^{2}=0.91$ for ${ }^{210} \mathrm{~Pb}$ dating).

\section{Discussion}

\section{Vertical Accretion Rates and Wetland Stability}

Based on the large number of stations with vertical accretion rates within the range of $0.2-0.5 \mathrm{~cm}$ year ${ }^{-1}$ across the midand high-marsh locations, we conclude that tidal wetlands across the Estuary are keeping pace with local SLR, which is very similar to global estimates (Flick et al. 2003; Cayan et al. 2008). The accretion rates from our study are slightly higher than the SLR rates over the last century when this sediment accumulated (IPCC 2007) and are similar to, or slightly higher than, the estimates of SLR rates for the last decade (Beckley et al. 2007). These data, however, primarily indicate that the marsh plain is keeping pace with recent SLR. The historic accretion rates should not be regarded as a maximum or direct predictor of future accretion rates because wetlands may respond to changes in SLR by accumulating additional sediment - or not. Models of wetland sediment dynamics (Callaway et al. 1996b; Temmerman et al. 2003; Rybcyzk and Callaway 2009; Kirwan et al. 2010) calibrated with historic sediment accretion data will be most useful in making realistic predictions of long-term wetland sustainability. The wetlands in South San Francisco Bay have demonstrated rapid rates of short-term accretion during 
Table 3 Average rates of vertical accretion, mineral accumulation, and carbon accumulation ( \pm standard error) based on both ${ }^{137} \mathrm{Cs}$ and ${ }^{210} \mathrm{~Pb}$ from low-, mid-, and high-marsh stations at all sampling sites $(n=2$ for all stations, except $n=1$ for Browns Island Low $\left({ }^{137} \mathrm{Cs}\right.$ and $\left.{ }^{210} \mathrm{~Pb}\right)$,
Petaluma River Low $\left({ }^{137} \mathrm{Cs}\right.$ and $\left.{ }^{210} \mathrm{~Pb}\right)$, Petaluma River High $\left({ }^{210} \mathrm{~Pb}\right.$ only), and Whale's Tail Mid and High ( ${ }^{137} \mathrm{Cs}$ only), and $n=3$ for Coon Island Mid $\left({ }^{137} \mathrm{Cs}\right.$ and $\left.{ }^{210} \mathrm{~Pb}\right)$ and High $\left({ }^{137} \mathrm{Cs}\right.$ only $\left.)\right)$

\begin{tabular}{|c|c|c|c|c|c|c|}
\hline \multirow[t]{2}{*}{ Site } & \multicolumn{2}{|l|}{ Low } & \multicolumn{2}{|l|}{ Mid } & \multicolumn{2}{|l|}{ High } \\
\hline & ${ }^{137} \mathrm{Cs}$ & ${ }^{210} \mathrm{~Pb}$ & ${ }^{137} \mathrm{Cs}$ & ${ }^{210} \mathrm{~Pb}$ & ${ }^{137} \mathrm{Cs}$ & ${ }^{210} \mathrm{~Pb}$ \\
\hline \multicolumn{7}{|c|}{ Vertical accretion $\left(\mathrm{cm}\right.$ year $\left.^{-1}\right)$} \\
\hline Browns Island & $0.45(n=1)$ & $0.26(n=1)$ & $0.40(0.03)$ & $0.32(0.12)$ & $0.35(0.02)$ & $0.27(0.01)$ \\
\hline Rush Ranch & $0.35(0.65)$ & $0.22(0.15)$ & $0.26(0.02)$ & $0.21(0.00)$ & $0.30(0.04)$ & $0.27(0.03)$ \\
\hline Brackish marsh means & 0.40 & 0.24 & 0.33 & 0.27 & 0.32 & 0.27 \\
\hline Coon Island & $0.68(0.09)$ & $0.45(0.13)$ & $0.18(0.04)$ & $0.15(0.02)$ & $0.32(0.07)$ & $0.22(0.08)$ \\
\hline Petaluma River & $0.34(n=1)$ & $0.24(n=1)$ & $0.27(0.07)$ & $0.26(0.04)$ & $0.25(0.05)$ & $0.19(n=1)$ \\
\hline China Camp & $0.63(0.22)$ & $0.43(0.09)$ & $0.36(0.03)$ & $0.35(0.04)$ & $0.28(0.00)$ & $0.32(0.12)$ \\
\hline Whale's Tail & $0.77(0.09)$ & & $0.57(n=1)$ & & $0.55(n=1)$ & \\
\hline Salt marsh means & 0.61 & 0.37 & 0.35 & 0.25 & 0.35 & 0.24 \\
\hline \multicolumn{7}{|c|}{ Mineral accumulation $\left(\mathrm{g} \mathrm{m}^{-2}\right.$ year $\left.^{-1}\right)$} \\
\hline Browns Island & $923(n=1)$ & $513(n=1)$ & $367(54.8)$ & $298(108.4)$ & $200(49.3)$ & $273(96.8)$ \\
\hline Rush Ranch & $1,215(208)$ & $772(144)$ & $305(34.5)$ & $320(7.1)$ & $521(200)$ & $597(26.9)$ \\
\hline Brackish marsh means & 1,069 & 643 & 336 & 309 & 361 & 435 \\
\hline Coon Island & $3,620(852)$ & $2,325(85.1)$ & $362(52.2)$ & $419(89.6)$ & $949(188)$ & $650(189)$ \\
\hline Petaluma River & $2,584(n=1)$ & $1,810(n=1)$ & $894(510)$ & $846(319)$ & $421(120)$ & $327(n=1)$ \\
\hline China Camp & $2,678(370)$ & $1,960(12.9)$ & $1,480(388)$ & $1,465(451)$ & $1,183(244)$ & $1,243(276)$ \\
\hline Whale's Tail & $4,257(491)$ & & $2,210(n=1)$ & & $2,129(n=1)$ & \\
\hline Salt marsh means & 3,467 & 1,960 & 1,845 & 1,465 & 1,656 & 1,243 \\
\hline \multicolumn{7}{|c|}{ Carbon sequestration $\left(\mathrm{g} \mathrm{m}^{-2}\right.$ year $\left.^{-1}\right)$} \\
\hline Browns Island & $158.4(n=1)$ & $88.9(n=1)$ & $157.9(7.7)$ & $116.9(37.0)$ & $151.8(22.2)$ & $116.5(3.7)$ \\
\hline Rush Ranch & $96.7(21.8)$ & $62.7(8.3)$ & $117.9(11.2)$ & $91.3(1.4)$ & $100.3(21.2)$ & $87.6(0.7)$ \\
\hline Brackish marsh means & 127.5 & 75.8 & 137.9 & 104.1 & 126.1 & 102.0 \\
\hline Coon Island & $187.5(44.9)$ & $111.2(37.8)$ & $52.3(8.1)$ & $40.4(4.9)$ & $89.6(17.5)$ & $52.7(17.5)$ \\
\hline Petaluma River & $87.7(n=1)$ & $57.1(n=1)$ & $66.2(12.6)$ & $57.5(7.8)$ & $58.7(5.1)$ & $48.0(n=1)$ \\
\hline China Camp & $141.9(44.3)$ & $95.8(17.9)$ & $79.8(6.9)$ & $72.0(6.2)$ & $87.0(5.0)$ & $90.8(35.9)$ \\
\hline Whale's Tail & $146.7(14.1)$ & & $117.9(n=1)$ & & $102.5(n=1)$ & \\
\hline Salt marsh means & 144.3 & 95.8 & 98.9 & 72.0 & 94.7 & 90.8 \\
\hline
\end{tabular}

periods of local subsidence, e.g., Alviso Slough (Patrick and DeLaune 1990) and Triangle Marsh (Watson 2004), indicating that these wetlands may be quite resilient to future increases in SLR.

Multiple low-marsh cores dated using ${ }^{137} \mathrm{Cs}$ dating had accretion rates of $0.6 \mathrm{~cm}_{\text {year }}{ }^{-1}$ or more, as did the relatively young site, WT (Appendix 8), indicating that wetlands may be able to keep pace with rates of SLR that are higher than the present values. However, the long-term reduction in suspended sediment concentrations in the Estuary over the last 30-50 years (Wright and Schoellhamer 2004) may compromise the ability of local wetlands to survive a future acceleration in SLR. This is of particular concern for salt marshes because they have a higher BD than brackish or freshwater tidal wetlands (Nyman et al. 1990; Table 2). Schoellhamer (2011) recently hypothesized that the Estuary may have shifted from a transport-regulated to a supplyregulated loading of suspended sediment because the easily erodible sediment pool within the Estuary has diminished. This may explain a recent and precipitous drop of $36 \%$ in suspended sediment concentration over the last 10 years. Both the broad long-term declines in suspended sediment concentration as well as this steep, recent drop could have large-scale implications for the future sediment availability and, therefore, the sustainability of wetlands and other intertidal habitats within the Estuary (Ganju and Schoellhamer 2010). This phenomenon of reduced sediment loads is not unique to San Francisco Bay Estuary, but has been found in 

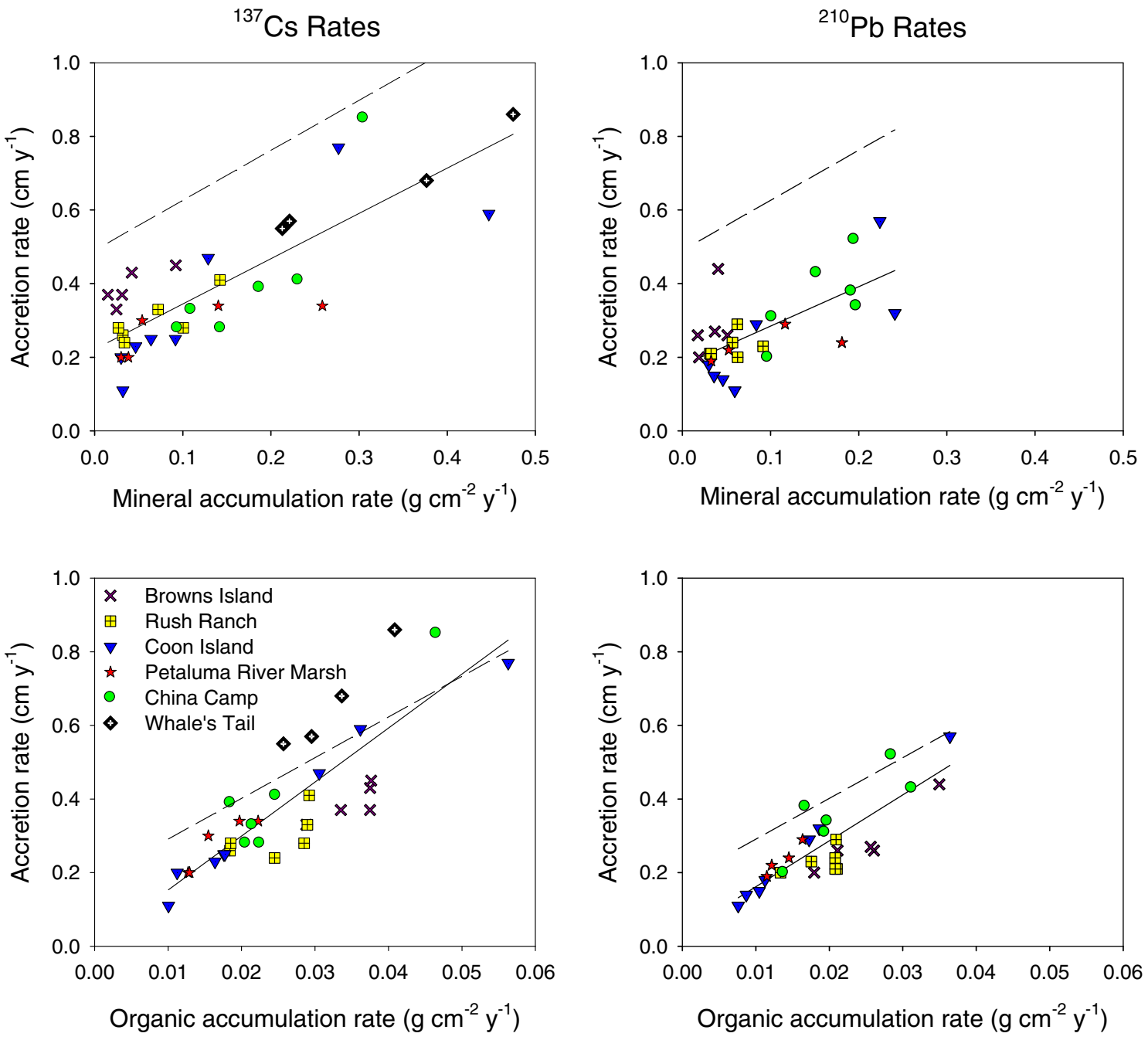

Fig. 3 Relationships between accretion rates and mineral accumulation (upper graphs) and carbon accumulation (lower graphs) based on both ${ }^{137} \mathrm{Cs}$ and ${ }^{210} \mathrm{~Pb}$ downcore distributions. The solid lines indicate regression lines for all sites; dashed lines indicate regression lines from

many watersheds because of the proliferation of dams and shifts in upstream land use (Ibàñez et al. 1996; Chen et al. 2001; Horowitz 2010; Tweel and Turner 2012).

There were few estimates of recent wetland sedimentation rates from the San Francisco Bay Estuary before this project, although a number of studies used either ${ }^{14} \mathrm{C}$ for long-term rates (Goman and Wells 2000; Byrne et al. 2001; Watson 2004; Drexler et al. 2009; Drexler 2011) or other methods for very short-term rates, e.g., 1-2 years (Reed 2002; Culberson et al. 2004). We are aware of no previous wetland sediment cores have been dated using ${ }^{210} \mathrm{~Pb}$ from the Estuary. In the only published study that used the downcore distributions of ${ }^{137} \mathrm{Cs}$ to date wetlands in the Estuary, Patrick and DeLaune (1990) evaluated three wetlands in South San Francisco Bay and found high rates of accretion (about $4 \mathrm{~cm}_{\text {year }}{ }^{-1}$ ) in one location and rates similar to our findings at the two other locations $\left(0.5\right.$ and $\left.0.4 \mathrm{~cm}_{\text {year }}{ }^{-1}\right)$.
Turner et al. (2000) based on ${ }^{137} \mathrm{Cs}$ dating. See Appendix 10 for additional information on relationships based on brackish and salt marsh sites

High rates of short-term sediment accretion have been documented for relatively young sites, including for naturally developing sites at $\sim 1 \mathrm{~cm} \mathrm{year}^{-1}$ (Watson 2008) and restored sites at $5-10 \mathrm{~cm}$ year $^{-1}$ (Williams and Orr 2002). Reed (2002) also measured accretion rates of $1 \mathrm{~cm}$ year ${ }^{-1}$ or more in a number of Delta wetlands, although the measurements represent only a 1-year period. It is unlikely that these short-term, very rapid rates of accretion would be sustained over long periods into the future, especially if suspended sediment concentrations continue to decline.

We hypothesized that the rate of sediment accretion would be highest in brackish wetlands because of the proximity of these sites to riverine sediment sources, and we were surprised that there was little variability in the accretion rates across sites. Whale's Tail was the one site with higher accretion rates based on ${ }^{137} \mathrm{Cs}$ dating (this could be due in part to its relatively young age), and there were no 
differences among sites based on ${ }^{210} \mathrm{~Pb}$ distributions (Table 3). We also hypothesized that, within wetlands, the accretion rates would be higher at sampling stations closer to the bay margin, as has been found in a number of previous studies of salt marshes (Pethick 1981; Hatton et al. 1983; Oenema and DeLaune 1988; French et al. 1995; Callaway et al. 1997). The data from this study provide mixed evidence to support this second hypothesis; the accretion rates from the low-marsh stations that were based on ${ }^{137} \mathrm{Cs}$ dating were significantly greater than at the highmarsh stations, but this was not the case for rates based on ${ }^{210} \mathrm{~Pb}$ dating (Table 3). The lack of variation in accretion rates based on ${ }^{210} \mathrm{~Pb}$ dating across the wetland may be due to the relatively high elevation and uniform conditions across the marsh plain in California tidal wetlands (Zedler et al. 1999). California tidal wetlands are characterized by a narrow band of $S$. foliosa or other low-marsh vegetation at the bay or tidal creek margins, in contrast to the broader expanse of low-marsh vegetation found in many Gulf of Mexico and East Coast S. alternifloradominated wetlands.

Accretion Vs. Mass-Based Accumulation: What Is Driving Accretion Rates?

Our data are consistent with previous studies which demonstrate a strong link between OM accumulation and vertical accretion rates (Nyman et al. 1993; Callaway et al. 1997; Turner et al. 2000). Although correlation of these values does not identify cause-effect relationships, these analyses have been widely used to gain insight into the relative importance of organic and mineral matter accumulation, both within local areas and across broader regions. The relationship between OM accumulation and the accretion rates from our data (accretion $=14.67 \times$ OMaccum. +0.006 ; Fig. 3 ) was similar to that from the review of 141 salt marshes on the Atlantic and Gulf Coasts (accretion $=11.06 \times \mathrm{OM}_{\text {accum. }}{ }^{+}$ 0.18; Turner et al. 2000), and the addition of our data to their dataset would strengthen that general relationship. The data points for mineral matter accumulation and accretion in our study were consistently below the relationship found for these variables from Turner et al. (2000), which we think is likely due to the high mineral content and the high BD of soils from San Francisco Bay tidal wetlands in comparison to those on the Gulf and Atlantic Coasts. Beyond these general trends, there were large differences in these relationships for salt and brackish wetlands in the Estuary, probably reflecting differences in sediment dynamics across these different wetland types.

In addition, there was more variation in mineral matter accumulation across sites than for either accretion or carbon accumulation. The coefficient of variation $(\mathrm{CV})$ for the average accretion rates across all sites was $30.4 \%$, while it was $25.0 \%$ for $\mathrm{OM}$ accumulation and $58.7 \%$ for mineral accumulation (based on ${ }^{137} \mathrm{Cs}$ dating). The data for $\mathrm{CVs}$ based on ${ }^{210} \mathrm{~Pb}$ dating showed a similar trend: $20.0 \%$ (accretion), $25.2 \%$ (OM accumulation), and $51.3 \%$ (mineral accumulation). These differences also support the concept of the importance of OM accumulation as a link to vertical accretion: mineral matter varies widely across these relatively similar sites, but both accretion and carbon accumulation were similar and more constant.

There was strong evidence from both dating methods to support our hypothesis that mineral matter accumulation would be greater at the low-marsh stations, but only mixed support for a similar trend in carbon accumulation (Table 3; Appendix 9). On the larger scale, it was surprising that our brackish wetland sites had the lowest rate of mineral sediment accumulation (Table 3), even though they are closer to the major inputs of mineral sediments (and freshwater) to the estuary, i.e., the Sacramento and San Joaquin Rivers. Our results are contrary to those from a number of other studies that have shown high rates of accretion rates and mineral matter accumulation in brackish and freshwater tidal wetlands (e.g., Craft 2007; Ibàñez et al. 2010). One brackish site, RR, is in the upper part of Suisun Bay and is somewhat removed from direct riverine inputs. We expected that it might have a low rate of mineral accumulation. The other brackish wetland, BRI, is very near the confluence of the Sacramento and San Joaquin Rivers, where we expected suspended sediment loads to be quite high; however, the mineral inputs at this site were $50 \%$ less than even the lowest salt marsh sites (Table 3). Darke and Megonigal (2003) found highly variable rates of short-term sediment accumulation in tidal freshwater wetlands near the Upper Chesapeake and attributed some of this variation to the proximity of the turbidity maximum. Similar spatial variation in the sediment dynamics within the Estuary likely affects mineral inputs to brackish wetlands as much of the sediment that enters the Sacramento-San Joaquin Delta is deposited there and does not move to the estuary (Wright and Schoellhamer 2005). Furthermore, the tidal range at BRI is reduced compared to the other sites (Table 1), and this could limit energy to move sediment from the Estuary into the adjacent wetlands.

Carbon Sequestration Rates and Management Implications

Data from our study substantially expand the spatial and temporal scope of carbon sequestration and accretion data across the Estuary and provide one of the most detailed datasets on recent carbon sequestration for a given estuary-something that is needed to evaluate the broader patterns of spatial and regional variability 
in carbon sequestration rates (McLeod et al. 2011). Although our average estimates for tidal salt and brackish wetlands in the Estuary $\left(111 \mathrm{~g} \mathrm{C} \mathrm{m}^{-2}\right.$ year $^{-1}$ when based on ${ }^{137} \mathrm{Cs}$ distributions from six sites; $79.3 \mathrm{~g} \mathrm{C} \mathrm{m}^{-2}$ year $^{-1}$ when based on ${ }^{210} \mathrm{~Pb}$ distributions from five sites) are below the global average of $220 \mathrm{~g} \mathrm{C} \mathrm{m}^{-2}$ year $^{-1}$ for tidal saline wetlands summarized by Chmura et al. (2003), they are similar to values published recently for other salt and brackish wetlands. Elsey-Quirk et al. (2011), for example, measured 119 and $154 \mathrm{~g} \mathrm{C} \mathrm{m}^{-2}$ year $^{-1}$ for single cores from $J$. roemerianus and $S$. alterniflora salt marshes in Delaware (based on ${ }^{137} \mathrm{Cs}$ distributions). The average sequestration rates based on ${ }^{137} \mathrm{Cs}$ distributions across three estuaries near Sapelo Island, Georgia, were 32, 21, and $108 \mathrm{~g} \mathrm{C} \mathrm{m}^{-2}$ year $^{-1}$ for the Doboy Sound, Sapelo, and Altamaha Rivers, respectively (Craft 2007), and the average rates were 124, 93, and $40 \mathrm{~g} \mathrm{C} \mathrm{m}^{-2}$ year $^{-1}$ for freshwater, brackish, and salt marshes, respectively, along three nearby estuaries (Ogeechee, Altamaha, and Satilla River estuaries; Loomis and Craft 2010).

The average estimate for tidal saline wetlands of $220 \mathrm{~g} \mathrm{C} \mathrm{m}^{-2}$ year $^{-1}$ from Chmura et al. (2003) is likely high because it includes rates that cover time spans from 1 to 100 years, and it includes a large number of data points from areas with exceptionally high values of carbon sequestration. The rates measured over short time periods are likely to be higher than those measured using longer-term dating methods. This has been shown with vertical accretion rates (Callaway et al. 1996b; Mudd et al. 2009) and is also true for carbon sequestration because of ongoing decomposition within the sediment column. The estimates of sequestration rates based on ${ }^{137} \mathrm{Cs}$ distributions (1963/1964 to present) were consistently higher than the estimates based on ${ }^{210} \mathrm{~Pb}$ distributions $(100+$ years $)$ found in our study. In addition, an inordinate number of the samples incorporated into the overall mean by Chmura et al. (2003) come from areas with relatively high rates of local subsidence (e.g., coastal Louisiana) or high-latitude, low-temperature coastal wetlands (e.g., Bay of Fundy), where sequestration rates are quite high. Some consideration of broader spatial and temporal patterns in carbon sequestration data should be incorporated into future estimates of the global averages. Even if previous global estimates of tidal wetland carbon sequestration area are slightly high, tidal wetlands still are likely to be high in terms of overall rates compared with other ecosystems (e.g., see reviews by Duarte et al. 2005; McLeod et al. 2011).

Our data showed little support for our hypothesis that brackish wetlands would have higher rates of $\mathrm{OM}$ and carbon accumulation, especially over the long term.
Browns Island (one of the two brackish sites) was the site with the highest carbon accumulation rates (156 and $117 \mathrm{~g} \mathrm{C} \mathrm{m}^{-2}$ year ${ }^{-1}$ based on ${ }^{137} \mathrm{Cs}$ and ${ }^{210} \mathrm{~Pb}$ dating, respectively), and it was statistically different from one of the five salt marshes dated using ${ }^{137} \mathrm{Cs}$ distributions. However, it was not statistically different from the other sites for carbon accumulation rates when based on ${ }^{210} \mathrm{~Pb}$ distributions. In addition, the second brackish wetland, $\mathrm{RR}$, had a rate of carbon sequestration that was very similar to the other locations $\left(80.5\right.$ vs. $69.5 \mathrm{~g} \mathrm{C} \mathrm{m}^{-2}$ year ${ }^{-1}$ from the three salt marsh sites based on ${ }^{210} \mathrm{~Pb}$ dating). In contrast to our findings, Loomis and Craft (2010) found that carbon sequestration rates were more than two times higher, on average, in brackish wetlands than in salt marshes (based on ${ }^{137} \mathrm{Cs}$ dating) from tidal wetlands within three estuaries in Georgia. Więski et al. (2010) also found significantly higher stocks of carbon across the same locations. Craft (2007), in a separate study, measured carbon sequestration in three nearby estuaries and found that carbon sequestration rates in tidal wetlands in freshwater-dominated systems were three to five times higher than the rates in marine-dominated wetlands. With the strong salt stress and gradients that are found in Mediterranean-type tidal wetlands, as well as the large differences in plant productivity within the estuary (Atwater et al. 1979), we expected to see strong differences here; further study is needed to explore potential causes for the observed lack of differences.

Given the need for long-term carbon burial to receive credits within the carbon trading program, we recommend that carbon credit accounting be based on sequestration rates obtained from ${ }^{210} \mathrm{~Pb}$ or other long-term dating methods. Sequestration rates that are based on short-term accretion are likely to overestimate carbon sequestration over a century timescale because much of the short-term accumulation will be eventually lost to belowground decomposition (e.g., see model results from Callaway et al. 1996a, b; Mudd et al. 2009). However, substantial carbon sequestration data already exist based on ${ }^{137} \mathrm{Cs}$ dating, and these data could be adjusted to compensate for differences in carbon sequestration over 30 - to 40 -year vs. 100 -year time frames. In the case of this study, the ${ }^{210} \mathrm{~Pb}$-based sequestration rates averaged approximately $73 \%$ of the ${ }^{137} \mathrm{Cs}$ rates (based on the five locations with both ${ }^{137} \mathrm{Cs}$ - and ${ }^{210} \mathrm{~Pb}$-dated cores); other studies have shown similar ratios between ${ }^{137} \mathrm{Cs}-$ and ${ }^{210} \mathrm{~Pb}$ based accretion rates, e.g., $75 \%$ from Turner et al. (2006). In cases where ${ }^{210} \mathrm{~Pb}$ data are not available, the accretion rates could be reduced by an average ratio such as this or by a regional or local ratio, if appropriate. While it is impossible to obtain long-term carbon sequestration rates from actual tidal wetland restoration sites, the use of natural tidal wetlands as surrogates is justified and is likely to give the best available estimate of the long-term carbon sequestration 
in restored tidal wetlands. The initial rates of vertical accretion will be high at restoration sites (Williams and Orr 2002); however, much of this accretion occurs before plant recruitment, and little carbon accumulation may occur under these circumstances. The rates of carbon accumulation based on ${ }^{137} \mathrm{Cs}$ distributions at WT (approx. 100 years old) were not different from the rates from historic salt marshes in the Estuary. We found slightly lower soil OM contents in restored salt marshes compared with natural salt marshes. However, the differences were not significant, and the OM content increased in the surface layers of both natural and restored wetland soils, supporting the hypothesis that natural sites serve as a good predictor of long-term dynamics in restoration sites.

Given the lack of statistical differences in ${ }^{210} \mathrm{~Pb}$-based carbon sequestration rates, both across sites and within sites, and the need for long-term carbon storage, we recommend that a single value be used in awarding credits for carbon sequestration for tidal wetland restoration projects within the Estuary: $79 \mathrm{~g} \mathrm{C} \mathrm{m}^{-2}$ year $^{-1}$ (based on ${ }^{210} \mathrm{~Pb}$ distributions). Our data did indicate slightly higher carbon sequestration rates at the one low-salinity brackish site (BRI). If future data analyses suggest that there are higher rates at similarly low-salinity sites, then the use of different credits for low-salinity brackish wetland restorations may be justified. However, methane emissions are likely to be a much greater issue at lowsalinity sites (Poffenbarger et al. 2011), and the effect of methane emissions on net carbon sequestration would have to be incorporated into any consideration of local carbon credits. Similarly, there was a difference in the short-term rates with higher sequestration rates at lowmarsh stations; however, the data based on rates over a 100 -year timescale using ${ }^{210} \mathrm{~Pb}$ distributions do not justify using different rates across a wetland. Furthermore, differences in the sequestration rates between mid- and highmarsh stations were minimal and never significant for either dating method. In most cases, the mid- and highmarsh stations had similar dominant plants, indicating that in other locations, it may be possible to stratify and reduce the sampling effort to determine carbon sequestration based on dominant vegetation.

Acknowledgments We thank the Gordon and Betty Moore Foundation for financial support for this research project. Site access and other support were provided by the California Department of Fish and Game, California State Coastal Conservancy, California State Parks, Don Edwards San Francisco Bay National Wildlife Refuge, East Bay Regional Park District, San Francisco Bay National Estuarine Research Reserve, and Solano Land Trust. Field and lab assistance was provided by Jennifer Gagnon, Mark Rosasco, and Andrea Torres. Valuable comments were provided on the manuscript by Steve Crooks, Judy Drexler, and two anonymous reviewers.

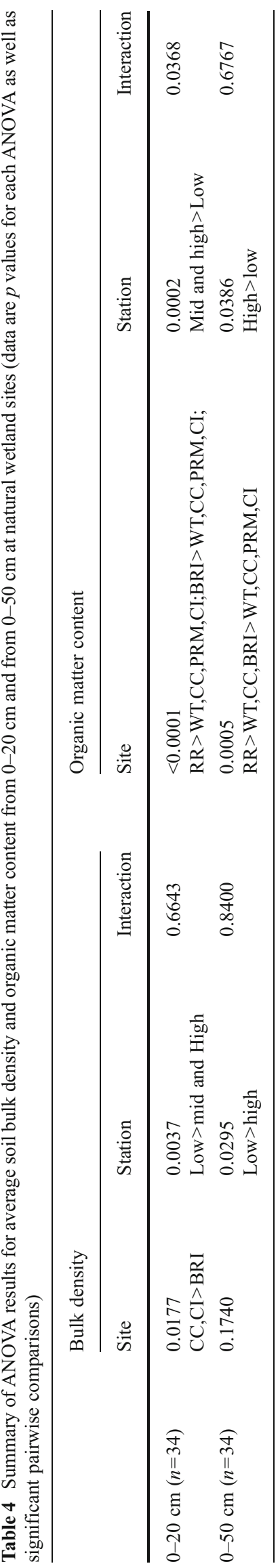




\section{Appendix 2}

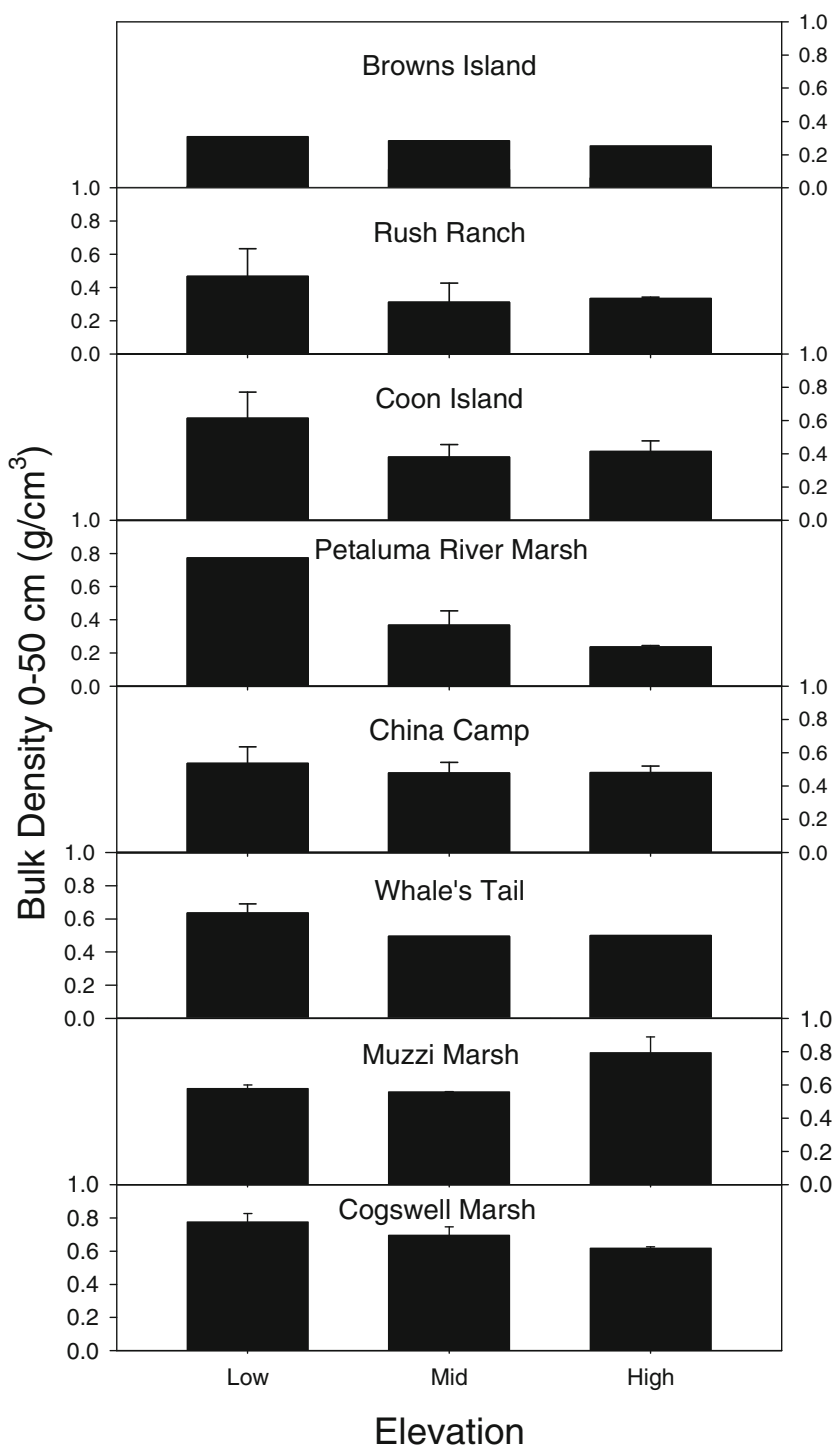

Fig. 4 Average sediment bulk density from 0 to $50 \mathrm{~cm}$ for cores from low-, mid-, and high-marsh stations at all sampling sites. Sample size for each location is indicated in Table 2. Error bars, $\pm 1 \mathrm{SE}$

\section{Appendix 3}

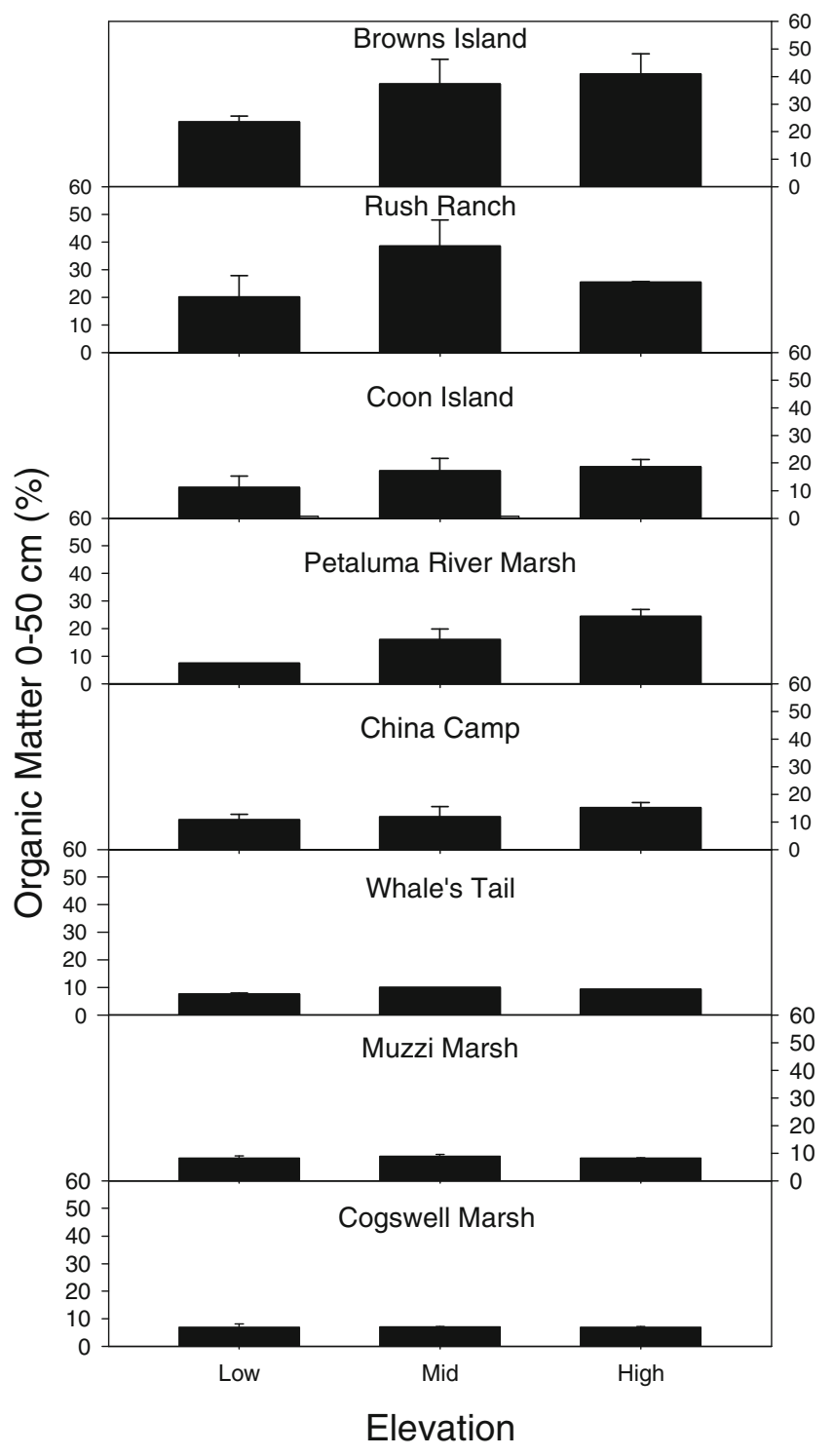

Fig. 5 Average sediment organic matter content from 0 to $50 \mathrm{~cm}$ for cores from low-, mid-, and high-marsh stations at all sampling sites. Sample size for each location is indicated in Table 2. Error bars, $\pm 1 \mathrm{SE}$ 


\section{Appendix 4}

\section{Organic Matter \%}

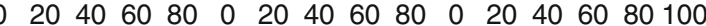
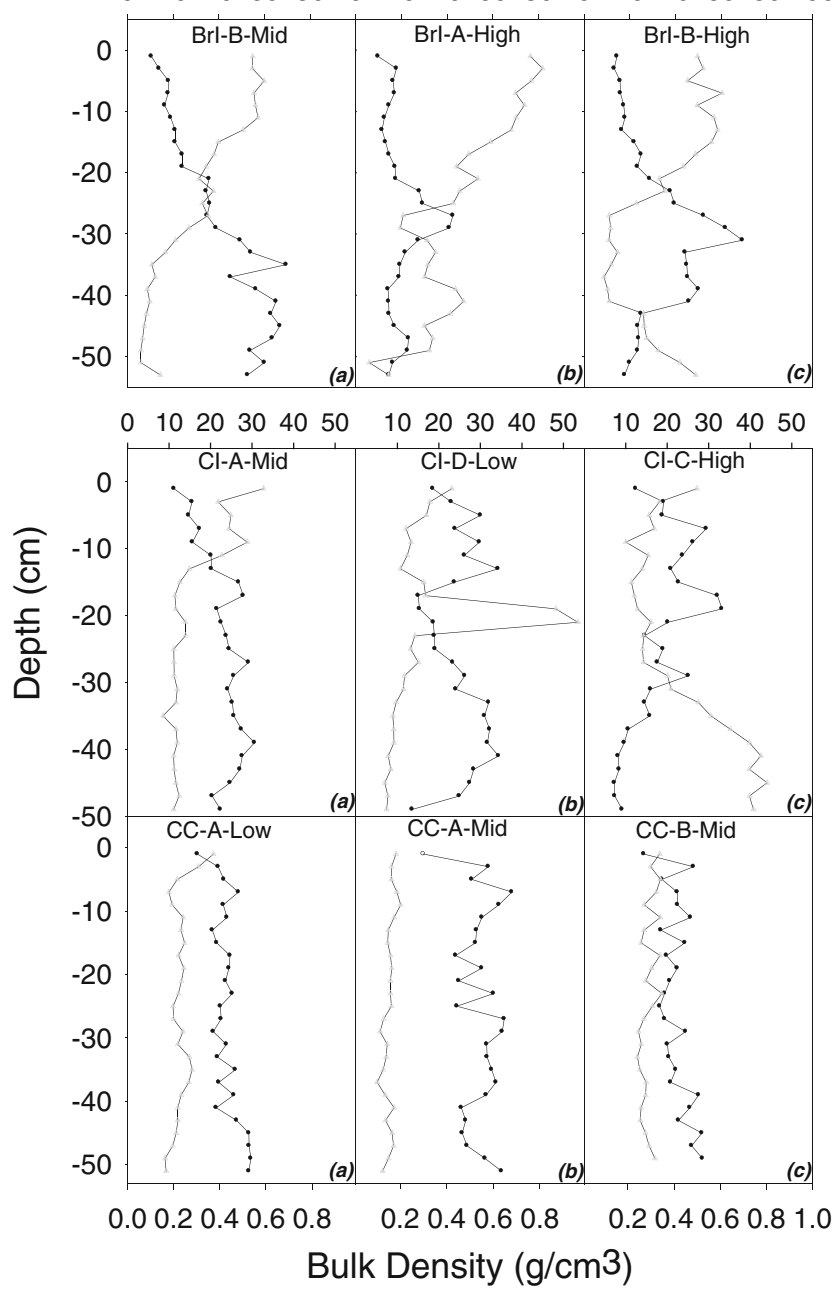

Fig. 6 Profiles of sediment bulk density and organic matter from 0 to $50 \mathrm{~cm}$ for selected cores from natural wetland sites

\section{Appendix 5}

\section{Organic Matter \%}

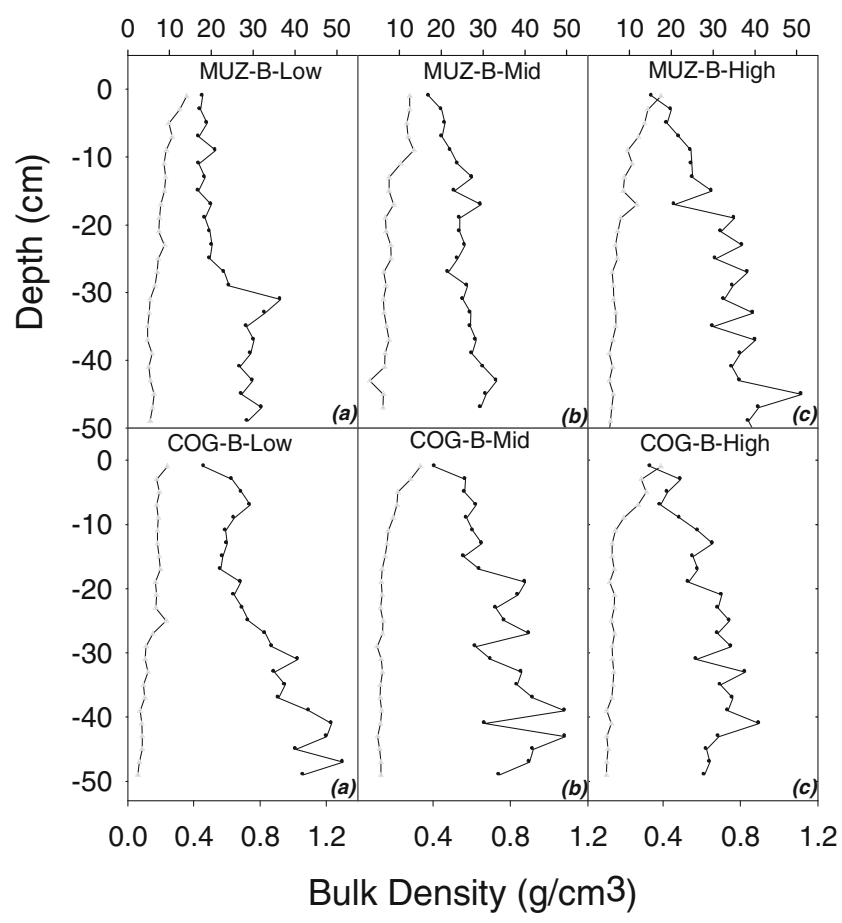

Fig. 7 Profiles of sediment bulk density and organic matter from 0 to $50 \mathrm{~cm}$ for selected cores from restored wetland sites

\section{Appendix 6}

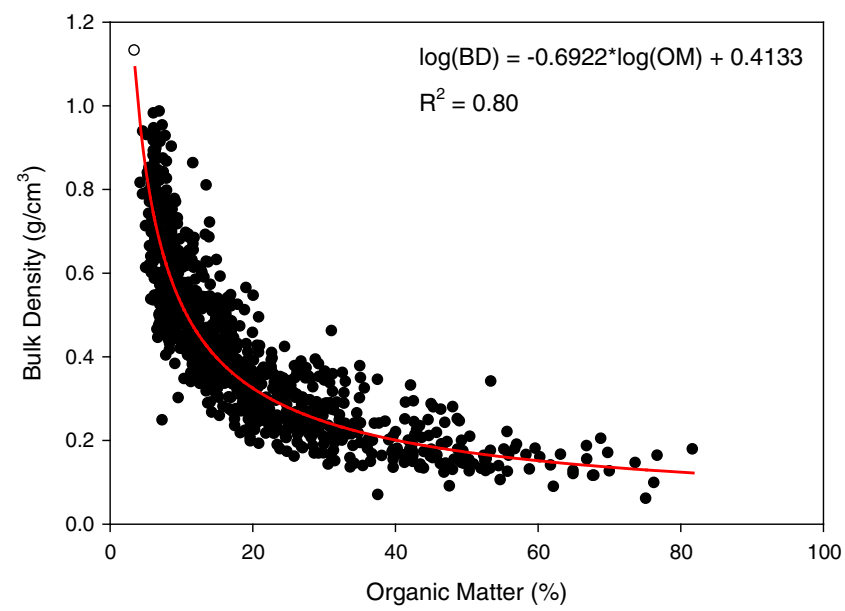

Fig. 8 Relationship between sediment organic matter content and bulk density based on sections from all cores 


\section{Appendix 7}

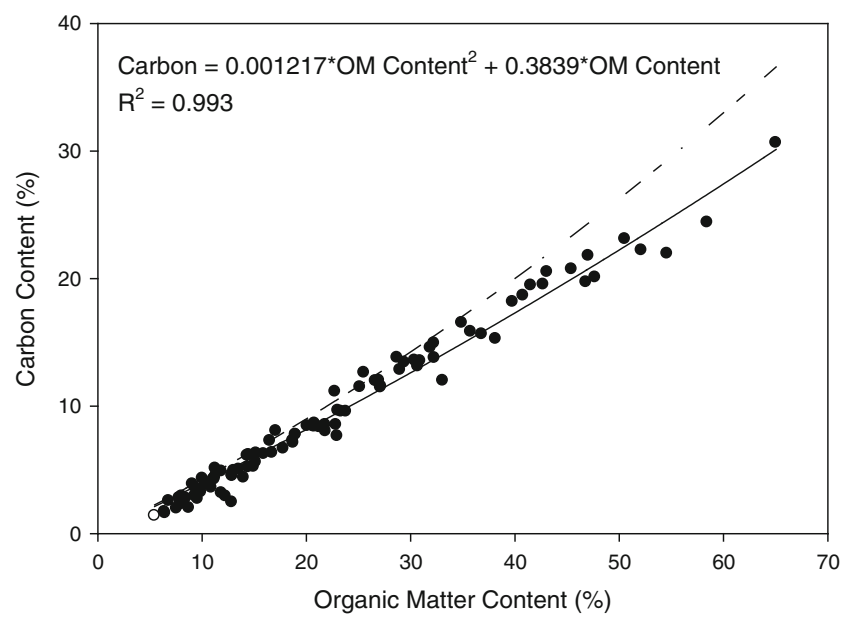

Fig. 9 Relationship between sediment organic matter content and carbon content based on data from 97 core sections. The solid line indicates the best fit regression for these data, and the dashed line indicates the regression equation from Craft et al. (1991)

\section{Appendix 8}

Table 5 Table of accretion rates, mineral matter, and carbon accumulation rates for all individual cores, with dating using downcore distributions of both ${ }^{137} \mathrm{Cs}$ and ${ }^{210} \mathrm{~Pb}$

\begin{tabular}{|c|c|c|c|c|c|c|c|c|}
\hline \multirow[t]{2}{*}{ Site } & \multirow[t]{2}{*}{ Station } & \multirow[t]{2}{*}{ Transect } & \multicolumn{3}{|c|}{ Rates based on ${ }^{137} \mathrm{Cs}$} & \multicolumn{3}{|c|}{ Rates based on ${ }^{210} \mathrm{~Pb}$} \\
\hline & & & $\begin{array}{l}\text { Accretion } \\
\left(\mathrm{cm}^{-1} \text { year }^{-1}\right)\end{array}$ & $\begin{array}{l}\text { Mineral accum. } \\
\left(\mathrm{g} \mathrm{m}^{-2} \text { year }^{-1}\right)\end{array}$ & $\begin{array}{l}\text { Carbon accum. } \\
\left(\mathrm{g} \mathrm{m}^{-2} \text { year }^{-1}\right)\end{array}$ & $\begin{array}{l}\text { Accretion } \\
\left(\mathrm{cm}^{-1} \text { year }^{-1}\right)\end{array}$ & $\begin{array}{l}\text { Mineral accum. } \\
\left(\mathrm{g} \mathrm{m}^{-2} \text { year }^{-1}\right)\end{array}$ & $\begin{array}{l}\text { Carbon accum. } \\
\left(\mathrm{g} \mathrm{m}^{-2} \text { year }^{-1}\right)\end{array}$ \\
\hline Whale's Tail & Low & $\mathrm{A}$ & 0.86 & $4,747.3$ & 160.8 & - & - & - \\
\hline Whale's Tail & Low & B & 0.68 & $3,765.7$ & 132.6 & - & - & - \\
\hline Whale's Tail & Mid & $\mathrm{A}$ & 0.57 & $2,210.5$ & 117.9 & - & - & - \\
\hline Whale's Tail & High & A & 0.55 & $2,129.3$ & 102.5 & - & - & - \\
\hline China Camp & Low & A & 0.85 & $3,047.6$ & 186.2 & 0.52 & $1,947.1$ & 113.8 \\
\hline China Camp & Low & $\mathrm{B}$ & 0.41 & $2,308.2$ & 97.5 & 0.34 & $1,972.9$ & 77.9 \\
\hline China Camp & Mid & A & 0.39 & $1,867.3$ & 72.9 & 0.38 & $1,915.8$ & 65.8 \\
\hline China Camp & Mid & $\mathrm{B}$ & 0.33 & $1,092.0$ & 86.7 & 0.31 & $1,014.3$ & 78.2 \\
\hline China Camp & High & A & 0.28 & 938.9 & 92.0 & 0.43 & $1,518.8$ & 126.7 \\
\hline China Camp & High & $\mathrm{B}$ & 0.28 & $1,427.0$ & 82.1 & 0.20 & 966.5 & 54.9 \\
\hline Petaluma River & Low & A & 0.34 & $2,584.5$ & 87.7 & 0.24 & $1,810.1$ & 57.1 \\
\hline Petaluma River & Mid & A & 0.2 & 383.7 & 53.6 & 0.22 & 527.8 & 49.7 \\
\hline Petaluma River & Mid & B & 0.34 & $1,403.7$ & 78.8 & 0.29 & $1,165.0$ & 65.4 \\
\hline Petaluma River & High & A & 0.2 & 301.4 & 53.5 & 0.19 & 327.0 & 48.0 \\
\hline Petaluma River & High & B & 0.3 & 541.3 & 63.8 & - & & \\
\hline Coon Island & Low & A & 0.59 & $4,472.9$ & 142.6 & 0.32 & $2,410.2$ & 73.4 \\
\hline Coon Island & Low & $\mathrm{D}$ & 0.77 & $2,768.0$ & 232.4 & 0.57 & $2,240.1$ & 149.0 \\
\hline Coon Island & Mid & A & 0.23 & 466.2 & 68.2 & 0.15 & 361.6 & 43.2 \\
\hline
\end{tabular}


Table 5 (continued)

\begin{tabular}{|c|c|c|c|c|c|c|c|c|}
\hline \multirow[t]{2}{*}{ Site } & \multirow[t]{2}{*}{ Station } & \multirow[t]{2}{*}{ Transect } & \multicolumn{3}{|c|}{ Rates based on ${ }^{137} \mathrm{Cs}$} & \multicolumn{3}{|c|}{ Rates based on ${ }^{210} \mathrm{~Pb}$} \\
\hline & & & $\begin{array}{l}\text { Accretion } \\
\left(\mathrm{cm}^{-1} \text { year }^{-1}\right)\end{array}$ & $\begin{array}{l}\text { Mineral accum. } \\
\left(\mathrm{g} \mathrm{m}^{-2} \text { year }^{-1}\right)\end{array}$ & $\begin{array}{l}\text { Carbon accum. } \\
\left(\mathrm{g} \mathrm{m}^{-2} \text { year }^{-1}\right)\end{array}$ & $\begin{array}{l}\text { Accretion } \\
\left(\mathrm{cm} \mathrm{year}^{-1}\right)\end{array}$ & $\begin{array}{l}\text { Mineral accum. } \\
\left(\mathrm{g} \mathrm{m}^{-2} \text { year }^{-1}\right)\end{array}$ & $\begin{array}{l}\text { Carbon accum. } \\
\left(\mathrm{g} \mathrm{m}^{-2} \text { year }^{-1}\right)\end{array}$ \\
\hline Coon Island & Mid & $\mathrm{B}$ & 0.11 & 320.1 & 41.7 & 0.11 & 595.0 & 30.9 \\
\hline Coon Island & Mid & $\mathrm{C}$ & 0.2 & 301.1 & 47.0 & 0.18 & 301.4 & 47.1 \\
\hline Coon Island & High & A & 0.25 & 640.2 & 72.3 & 0.29 & 839.0 & 70.2 \\
\hline Coon Island & High & $\mathrm{B}$ & 0.47 & $1,288.7$ & 124.7 & - & - & - \\
\hline Coon Island & High & $\mathrm{C}$ & 0.25 & 918.3 & 71.9 & 0.14 & 460.3 & 35.3 \\
\hline Rush Ranch & Low & A & 0.41 & $1,423.1$ & 118.4 & 0.23 & 916.3 & 71.0 \\
\hline Rush Ranch & Low & $\mathrm{B}$ & 0.28 & $1,006.4$ & 74.9 & 0.20 & 628.2 & 54.4 \\
\hline Rush Ranch & Mid & A & 0.28 & 270.9 & 129.1 & 0.21 & 312.7 & 92.7 \\
\hline Rush Ranch & Mid & $\mathrm{B}$ & 0.24 & 340.0 & 106.7 & 0.21 & 326.8 & 90.0 \\
\hline Rush Ranch & High & A & 0.26 & 321.1 & 79.1 & 0.29 & 623.8 & 88.2 \\
\hline Rush Ranch & High & B & 0.33 & 720.3 & 121.5 & 0.24 & 569.9 & 86.9 \\
\hline Browns Island & Low & B & 0.45 & 922.9 & 158.4 & 0.26 & 513.3 & 88.9 \\
\hline Browns Island & Mid & A & 0.43 & 421.9 & 165.5 & 0.44 & 406.4 & 153.9 \\
\hline Browns Island & Mid & B & 0.37 & 312.3 & 150.2 & 0.2 & 189.7 & 79.9 \\
\hline Browns Island & High & A & 0.37 & 151.1 & 174.1 & 0.26 & 176.1 & 120.2 \\
\hline Browns Island & High & B & 0.33 & 249.6 & 129.6 & 0.27 & 369.7 & 112.9 \\
\hline
\end{tabular}

\section{Appendix 9}

Table 6 Summary of ANOVA results for accretion rates and mass-based accumulation rates (data are $p$ values for each ANOVA as well as significant pairwise comparisons)

\begin{tabular}{|c|c|c|c|c|c|c|c|c|c|}
\hline & \multicolumn{3}{|c|}{ Accretion rates } & \multicolumn{3}{|l|}{ Mineral accumulation } & \multicolumn{3}{|c|}{ Carbon accumulation } \\
\hline & Site & Station & Interact. & Site & Station & Interact. & Site & Station & Interact. \\
\hline $\begin{array}{l}{ }^{137} \mathrm{Cs} \\
(n=34)\end{array}$ & $\begin{array}{l}0.0104 \\
\text { WT }> \\
\text { PRM, } \\
\text { CI,RR }\end{array}$ & $\begin{array}{l}0.0036 \\
\text { Low }>\text { mid } \\
\text { and high }\end{array}$ & 0.1681 & $\begin{array}{l}<0.0001 \\
\text { WT }>\text { PRM,CI,RR,BRI;CC }> \\
\text { RR,BRI; CI }>\text { BRI }\end{array}$ & $\begin{array}{c}<0.0001 \\
\text { Low }> \\
\text { mid } \\
\text { and } \\
\text { high }\end{array}$ & 0.0556 & $\begin{array}{l}0.0059 \\
\mathrm{BRI}>\mathrm{PRM}, \mathrm{CI}\end{array}$ & $\begin{array}{l}0.0150 \\
\text { Low> } \\
\text { mid } \\
\text { and } \\
\text { high }\end{array}$ & 0.0683 \\
\hline $\begin{array}{l}{ }^{210} \mathrm{~Pb} \\
\quad(n=28)\end{array}$ & 0.1662 & 0.3110 & 0.2431 & $\begin{array}{l}0.0002 \\
\mathrm{CC}>\mathrm{RR}, \mathrm{BRI} ; \mathrm{PRM}>\mathrm{BRI} \text {; } \mathrm{CI}> \\
\text { BRI }\end{array}$ & $\begin{array}{l}0.0003 \\
\text { Low> } \\
\text { mid } \\
\text { and } \\
\text { high }\end{array}$ & 0.0944 & $\begin{array}{l}0.0437 \\
\text { None }<0.05\end{array}$ & 0.7160 & 0.2089 \\
\hline
\end{tabular}

\section{Appendix 10}

Table 7 Regression results $\left(r^{2}\right.$ values) for comparisons between accretion rates and mineral and organic matter accumulation rates based on both ${ }^{137} \mathrm{Cs}$ and ${ }^{210} \mathrm{~Pb}$ data (from all sites and separately from salt marsh and tidal brackish wetland sites)

\begin{tabular}{llrlr}
\hline & \multicolumn{2}{l}{ Mineral accumulation vs. accretion } & & \multicolumn{2}{l}{ Organic accumulation vs. accretion } \\
\cline { 2 - 3 } & \multicolumn{1}{l}{${ }^{137} \mathrm{Cs}$} & ${ }^{210} \mathrm{~Pb}$ & $0.700(n=34)$ & ${ }^{137} \mathrm{Cs}$ \\
\hline All sites & $0.682(n=34)$ & $0.443(n=28)$ & $0.872(n=23)$ & $0.702(n=28)$ \\
Salt & $0.758(n=23)$ & $0.618(n=17)$ & $0.681(n=11)$ & $0.768(n=17)$ \\
Brackish & $0.124(n=11)$ & $<0.001(n=11)$ & $0.71)$ \\
\hline
\end{tabular}




\section{References}

Allen, J.R.L. 2000. Morphodynamics of Holocene salt marshes: a review sketch from the Atlantic and Southern North Sea coasts of Europe. Quaternary Science Reviews 19: 1155-1231.

Atwater, B.F., S.G. Conard, J.N. Dowden, C.W. Hedel, R.L. MacDonald, and W. Savage. 1979. History, landforms, and vegetation of the estuary's tidal marshes. In San Francisco Bay: the urbanized estuary, ed. T.J. Conomos, 347-385. San Francisco: Pacific Division, American Association for the Advancement of Science.

Ball, D.F. 1964. Loss-on-ignition as an estimate of organic matter and organic carbon in non-calcareous soils. Journal of Soil Science 15: 84-92.

Bartlett, K.B., and R.C. Harriss. 1993. Review and assessment of methane emissions from wetlands. Chemosphere 26: 261-320.

Beckley, B.D., F.G. Lemoine, S.B. Luthcke, R.D. Ray, and N.P. Zelensky. 2007. A reassessment of global and regional mean sea level trends from TOPEX and Jason-1 altimetry based on revised reference frame and orbits. Geophysical Research Letters 34: Article no. L14608. doi:14610.11029/12007g1030002.

Binford, M.W. 1990. Calculation and uncertainty analysis of ${ }^{210} \mathrm{~Pb}$ dates for PIRLA project lake sediment cores. Journal of Paleolimnology 3: 253-267.

Bridgham, S.D., J.P. Megonigal, J.K. Keller, N.B. Bliss, and C. Trettin. 2006. The carbon balance of North American wetlands. Wetlands 26: 889-916.

Byrne, R., B.L. Ingram, S. Starratt, F. Malamud-Roam, J.N. Collins, and M.E. Conrad. 2001. Carbon-isotope, diatom, and pollen evidence for Late Holocene salinity change in a brackish marsh in the San Francisco Estuary. Quaternary Research 55: 66-76.

Callaway, J.C. 2001. Hydrology and substrate. In Handbook for restoring tidal wetlands, ed. J.B. Zedler, 89-117. Boca Raton: CRC.

Callaway, J.C., A.B. Borde, H.L. Diefenderfer, V.T. Parker, J.M. Rybcyzk, and R.M. Thom. 2012. Pacific Coast tidal wetlands. In Wetland habitats of North America: ecology and conservation concerns, eds. D. P. Batzer and A. H. Baldwin, 103-116. Berkeley, CA: University of California Press.

Callaway, J.C., R.D. DeLaune, and W.H. Patrick Jr. 1996a. Chernobyl ${ }^{137} \mathrm{Cs}$ used to determine sediment accretion rates at selected northern European coastal wetlands. Limnology and Oceanography 41: 444-450.

Callaway, J.C., R.D. DeLaune, and W.H. Patrick Jr. 1997. Sediment accretion rates from four coastal wetlands along the Gulf of Mexico. Journal of Coastal Research 13: 181-191.

Callaway, J.C., J.A. Nyman, and R.D. DeLaune. 1996b. Sediment accretion in coastal wetlands: a review and a simulation model of processes. Current Topics in Wetland Biogeochemistry 2: 2-23.

Cayan, D.R., P.D. Bromirski, K. Hayhoe, M. Tyree, M.D. Dettinger, and R.E. Flick. 2008. Climate change projections of sea level extremes along the California coast. Climatic Change 87: S57-S73.

Chen, Z.Y., J.F. Li, H.T. Shen, and Z.H. Wang. 2001. Yangtze River of China: historical analysis of discharge variability and sediment flux. Geomorphology 41: 77-91.

Chmura, G.L., S.C. Anisfeld, D.R. Cahoon, and J.C. Lynch. 2003. Global carbon sequestration in tidal, saline wetland soils. Global Biogeochemical Cycles 17: Article no. 1111. doi:1110.1029/ 2002GB001917

Connor, R.F., G.L. Chmura, and C.B. Beecher. 2001. Carbon accumulation in Bay of Fundy salt marshes: implications for restoration of reclaimed marshes. Global Biogeochemical Cycles 15: 943-954.

Craft, C. 2007. Freshwater input structures soil properties, vertical accretion, and nutrient accumulation of Georgia and U.S. tidal marshes. Limnology and Oceanography 52: 1220-1230.

Craft, C.B., E.D. Seneca, and S.W. Broome. 1991. Loss on ignition and Kjeldahl digestion for estimating organic carbon and total nitrogen in estuarine marsh soils: calibration with dry combustion. Estuaries 14: 175-179.
Crooks, S., S. Emmett-Mattox, and J. Findsen. 2010. Findings of the National Blue Ribbon Panel on the Development of a Greenhouse Gas Offset Protocol for Tidal Wetlands Restoration and Management: action plan to guide protocol development: Restore America's Estuaries, Philip Williams \& Associates, Ltd., and Science Applications International Corporation. http://estuaries.org/climate-change.html. Accessed 3 Feb 2012

Culberson, S.D., T.C. Foin, and J.N. Collins. 2004. The role of sedimentation in estuarine marsh development within the San Francisco Estuary, California, USA. Journal of Coastal Research 20: 970-979.

Darke, A.K., and J.P. Megonigal. 2003. Control of sediment deposition rates in two mid-Atlantic Coast tidal freshwater wetlands. Estuarine Coastal and Shelf Science 57: 255-268.

Drexler, J.Z. 2011. Peat formation processes through the millennia in tidal marshes of the Sacramento-San Joaquin Delta, California, USA. Estuaries and Coasts 34: 900-911. doi:910.1007/s1223712011-19393-12237.

Drexler, J.Z., C.S. de Fontaine, and T.A. Brown. 2009. Peat accretion histories during the past 6,000 years in marshes of the SacramentoSan Joaquin Delta, CA, USA. Estuaries and Coasts 32: 871-892.

Duarte, C.M., J.J. Middelburg, and N. Caraco. 2005. Major role of marine vegetation on the oceanic carbon cycle. Biogeosciences 2: 1-8.

Elsey-Quirk, T., D.M. Seliskar, C.K. Sommerfield, and J.L. Gallagher. 2011. Salt marsh carbon pool distribution in a Mid-Atlantic lagoon, USA: sea level rise implications. Wetlands 31: 87-99.

Emmett, R., R. Llanso, J. Newton, R. Thom, M. Hornberger, C. Morgan, C. Levings, A. Copping, and P. Fishman. 2000. Geographic signatures of North American West Coast estuaries. Estuaries 23: 765-792.

Emmett-Mattox, S., S. Crooks, and J. Findsen. 2011. Gases and grasses: the restoration, conservation, or avoided loss of tidal wetlands carbon pools may help to mitigate climate change. The Environmental Forum 28: 30-35.

Flick, R.E., J.F. Murray, and L.C. Ewing. 2003. Trends in United States tidal datum statistics and tide range. Journal of Waterway, Port, Coastal, and Ocean Engineering 129: 155-164.

Freedman, B., G. Stinson, and P. Lacoul. 2009. Carbon credits and the conservation of natural areas. Environmental Reviews 17: 1-19.

French, J.R., T. Spencer, A.L. Murray, and N.S. Arnold. 1995. Geostatistical analysis of sediment deposition in two small tidal wetlands, Norfolk, U.K. Journal of Coastal Research 11: 308-321.

Friedrichs, C.T., and J.E. Perry. 2001. Tidal salt marsh morphodynamics: a synthesis. Journal of Coastal Research Special Issue 27: 7-37.

Ganju, N.K., and D.H. Schoellhamer. 2010. Decadal-timescale estuarine geomorphic change under future scenarios of climate and sediment supply. Estuaries and Coasts 33: 15-29.

Gee, G.W., and J.W. Bauder. 1986. Particle-size analysis. In Methods of soil analysis: Part I: Physical and mineralogical methods, ed. A. Klute, 383-411. Madison: American Society of Agronomy.

Goman, M., and L. Wells. 2000. Trends in river flow affecting the northeastern reach of the San Francisco Bay estuary over the past 7000 years. Quaternary Research 54: 206-217.

Hansen, L.T. 2009. The viability of creating wetlands for the sale of carbon offsets. Journal of Agricultural and Resource Economics 34: 350-365.

Hargis, T.G., and R.R. Twilley. 1994. Improved coring device for measuring soil bulk density in a Louisiana deltaic marsh. Journal of Sedimentary Research Section A: Sedimentary Petrology and Processes 64: 681-683.

Hatton, R.S., R.D. DeLaune, and W.H. Patrick Jr. 1983. Sedimentation, accretion, and subsidence in marshes of Barataria Basin, Louisiana. Limnology and Oceanography 28: 494-502.

Horowitz, A.J. 2010. A quarter century of declining suspended sediment fluxes in the Mississippi River and the effect of the 1993 flood. Hydrological Processes 24: 13-34.

Hussein, A.H., M.C. Rabenhorst, and M.L. Tucker. 2004. Modeling of carbon sequestration in coastal marsh soils. Soil Science Society of America Journal 68: 1786-1795. 
Ibàñez, C., N. Prat, and A. Canicio. 1996. Changes in the hydrology and sediment transport produced by large dams on the lower Ebro river and its estuary. Regulated Rivers-Research \& Management 12: 51-62.

Ibàñez, C., P.J. Sharpe, J.W. Day, J.N. Day, and N. Prat. 2010. Vertical accretion and relative sea level rise in the Ebro Delta wetlands (Catalonia, Spain). Wetlands 30: 979-988.

IPCC. 2007. Climate change 2007: The physical science basis: summary for policymakers. www.ipcc.ch. Accessed 3 Feb 2012.

Kayranli, B., M. Scholz, A. Mustafa, and A. Hedmark. 2010. Carbon storage and fluxes within freshwater wetlands: a critical review. Wetlands 30: 111-124.

Kirwan, M.L., G.R. Guntenspergen, A. D'Alpaos, J.T. Morris, S.M. Mudd, and S. Temmerman. 2010. Limits on the adaptability of coastal marshes to rising sea level. Geophysical Research Letters 37: Article no. L23401. doi:23410.21029/22010g1045489

Laffoley, D., and G. Grimsditch (eds.). 2009. The management of natural coastal carbon sinks. Gland: IUCN.

Loomis, M.J., and C.B. Craft. 2010. Carbon sequestration and nutrient (nitrogen, phosphorus) accumulation in river-dominated tidal marshes, Georgia, USA. Soil Science Society of America Journal 74: 1028-1036.

Magenheimer, J.F., T.R. Moore, G.L. Chmura, and R.J. Daoust. 1996. Methane and carbon dioxide flux from a macrotidal salt marsh, Bay of Fundy, New Brunswick. Estuaries 19: 139-145.

McLeod, E., G.L. Chmura, S. Bouillon, R. Salm, M. Björk, C.M. Duarte, C.E. Lovelock, W.H. Schlesinger, and B.R. Silliman. 2011. A blueprint for blue carbon: toward an improved understanding of the role of vegetated coastal habitats in sequestering $\mathrm{CO}_{2}$. Frontiers in Ecology and the Environment 9: 552-560.

Michener, W.K., E.R. Blood, K.L. Bildstein, M.M. Brinson, and L.R. Gardner. 1997. Climate change, hurricanes and tropical storms, and rising sea level in coastal wetlands. Ecological Applications 7: 770-801.

Milan, C.S., E.M. Swenson, R.E. Turner, and J.M. Lee. 1995. Assessment of the ${ }^{137} \mathrm{Cs}$ method for estimating sediment accumulation rates: Louisiana salt marshes. Journal of Coastal Research 11: 296-307.

Miller, R.L., and R. Fujii. 2010. Plant community, primary productivity, and environmental conditions following wetland re-establishment in the Sacramento-San Joaquin Delta, California. Wetlands Ecology and Management 18: 1-16.

Morris, J.T., P.V. Sundareshwar, C.T. Nietch, B. Kjerfve, and D.R. Cahoon. 2002. Responses of coastal wetlands to rising sea level. Ecology 83: 2869-2877.

Mudd, S.M., S.M. Howell, and J.T. Morris. 2009. Impact of dynamic feedbacks between sedimentation, sea-level rise, and biomass production on near-surface marsh stratigraphy and carbon accumulation. Estuarine Coastal and Shelf Science 82: 377-389.

Neubauer, S.C. 2008. Contributions of mineral and organic components to tidal freshwater marsh accretion. Estuarine Coastal and Shelf Science 78: 78-88.

Nyman, J.A., R.D. DeLaune, and W.H. Patrick Jr. 1990. Wetland soil formation in the rapidly subsiding Mississippi River Deltaic Plain: mineral and organic matter relationships. Estuarine, Coastal and Shelf Science 31: 57-69.

Nyman, J.A., R.D. DeLaune, H.H. Roberts, and W.H. Patrick Jr. 1993. Relationship between vegetation and soil formation in a rapidly submerging coastal marsh. Marine Ecology Progress Series 96: 269-278.

Oenema, O., and R.D. DeLaune. 1988. Accretion rates in salt marshes in the Eastern Scheldt, south-west Netherlands. Estuarine, Coastal and Shelf Science 26: 379-394.

Patrick Jr., W.H., and R.D. DeLaune. 1990. Subsidence, accretion, and sea level rise in south San Francisco Bay marshes. Limnology and Oceanography 35: 1389-1395.

Pethick, J.S. 1981. Long-term accretion rates on tidal salt marshes. Journal of Sedimentary Petrology 51: 521-577.

Poffenbarger, H., B. Needelman, and J. Megonigal. 2011. Salinity influence on methane emissions from tidal marshes. Wetlands 31: 831-842.
Rahmstorf, S. 2007. A semi-empirical approach to projecting future sea-level rise. Science 315: 368-370.

Reed, D.J. 2002. Understanding tidal marsh sedimentation in the Sacramento-San Joaquin Delta, California. Journal of Coastal Research Special Issue 36: 605-611.

Robbins, J.A., D.N. Edgington, and A.L.W. Kemp. 1978. Comparative ${ }^{210} \mathrm{~Pb},{ }^{137} \mathrm{Cs}$ and pollen geochronologies of sediments from Lakes Ontario and Erie. Quaternary Research 10: 256-278.

Rybcyzk, J.M., and J.C. Callaway. 2009. Surface elevation models. In Coastal wetlands: an integrated ecosystem approach, ed. G.M.E. Perillo, E. Wolanski, D.R. Cahoon, and M.M. Brinson, 835-854. Amsterdam: Elsevier Science.

Shoellhamer, D.H. 2011. Sudden clearing of estuarine waters upon crossing the threshold from transport to supply regulation of sediment transport as an erodible sediment pool is depleted: San Francisco Bay, 1999. Estuaries and Coasts 34: 885-899.

Stevenson, J.C., L.G. Ward, and M.S. Kearney. 1986. Vertical accretion in marshes with varying rates of sea level rise. In Estuarine variability, ed. D.A. Wolfe, 241-259. San Diego: Academic.

SYSTAT Software Inc. 2007. SYSTAT 12. Chicago: SYSTAT Software, Inc.

Temmerman, S., G. Govers, P. Meire, and S. Wartel. 2003. Modelling long-term tidal marsh growth under changing tidal conditions and suspended sediment concentrations, Scheldt estuary, Belgium. Marine Geology 193: 151-169.

Turner, R.E., C.S. Milan, and E.M. Swenson. 2006. Recent volumetric changes in salt marsh soils. Estuarine Coastal and Shelf Science 69: 352-359.

Turner, R.E., E.M. Swenson, and C.S. Milan. 2000. Organic and inorganic contributions to vertical accretion in salt marsh sediments. In Concepts and controversies in tidal marsh ecology, ed. M.P. Weinstein and D.A. Kreeger, 583-595. Boston: Kluwer Academic.

Tweel, A.W., and R.E. Turner. 2012. Watershed land use and river engineering drive wetland formation and loss in the Mississippi River birdfoot delta. Limnology and Oceanography 57: $18-28$.

Vermeer, M., and S. Rahmstorf. 2009. Global sea level linked to global temperature. Proceedings of the National Academy of Sciences of the United States of America 106: 21527-21532.

Watson, E.B. 2004. Changing elevation, accretion, and tidal marsh plant assemblages in a South San Francisco Bay tidal marsh. Estuaries 27: 684-698.

Watson, E.B. 2008. Marsh expansion at Calaveras Point Marsh, South San Francisco Bay, California. Estuarine Coastal and Shelf Science 78: 593-602.

Więski, K., H.Y. Guo, C.B. Craft, and S.C. Pennings. 2010. Ecosystem functions of tidal fresh, brackish, and salt marshes on the Georgia Coast. Estuaries and Coasts 33: 161-169.

Williams, P.B., and P.M. Faber. 2001. Salt marsh restoration experience in the San Francisco Bay estuary. Journal of Coastal Research Special Issue 27: 203-211.

Williams, P.B., and M.K. Orr. 2002. Physical evolution of restored breached levee salt marshes in the San Francisco Bay estuary. Restoration Ecology 10: 527-542.

Wright, S.A., and D.H. Schoellhamer. 2004. Trends in the sediment yield of the Sacramento River, California, 1957-2001. San Francisco Estuary and Watershed Science 2: Article 2. http://repositories. cdlib.org/jmie/sfews/vol2/iss2/art2. Accessed 3 Feb 2012.

Wright, S.A., and D.H. Schoellhamer. 2005. Estimating sediment budgets at the interface between rivers and estuaries with application to the Sacramento-San Joaquin River Delta. Water Resources Research 41: W09428.

Zedler, J.B., J.C. Callaway, J.S. Desmond, G. Vivian-Smith, G.D. Williams, G. Sullivan, A.E. Brewster, and B.K. Bradshaw. 1999. Californian salt-marsh vegetation: an improved model of spatial pattern. Ecosystems 2: 19-35. 